\title{
Development and Optimization of a Carbon Dioxide-Aided Cold Microfiltration Process for the Physical Removal of Microorganisms and Somatic Cells from Skim Milk
}

\author{
J. Fritsch and C. I. Moraru ${ }^{1}$ \\ Department of Food Science, Cornell University, Ithaca, NY 14853
}

\begin{abstract}
Physical removal of microorganisms from skim milk by microfiltration (MF) is becoming increasingly attractive to the dairy industry. Typically, this process is performed at temperatures of approximately $50^{\circ} \mathrm{C}$. Additional shelf-life and quality benefits might be gained by conducting the MF process at low temperatures. Cold MF could also minimize microbial fouling of the membrane and prevent the germination of thermophilic spores. The objective of this study was to optimize a cold MF process for the effective removal of microbial and somatic cells from skim milk. An experimental MF setup containing a tubular Tami ceramic membrane with a nominal pore size of $1.4 \mu \mathrm{m}$ was used for MF of raw skim milk at a temperature of 6 $\pm 1^{\circ} \mathrm{C}$. The processing conditions used were cross-flow velocities of 5 to $7 \mathrm{~m} / \mathrm{s}$, and transmembrane pressures of 52 to $131 \mathrm{kPa}$. All MF experiments were performed in triplicate. The permeate flux was determined gravimetrically. Microbiological, chemical, and somatic cell analyses were performed to evaluate the effect of MF on the composition of skim milk. The permeate flux increased drastically when velocity was increased from 5 to $7 \mathrm{~m} / \mathrm{s}$. The critical transmembrane pressure range conducive to maximum fluxes was 60 to $85 \mathrm{kPa}$. When MF was conducted under optimal conditions, very efficient removal of vegetative bacteria, spores, and somatic cells, as well as near complete transmission of proteins into the MF milk, was achieved. To further enhance the flux, a $\mathrm{CO}_{2}$ backpulsing system was developed. This technique is able both to increase the flux and to maintain it steadily for an extended period of time. The $\mathrm{CO}_{2}$-aided cold MF process has the potential to become economically attractive to the dairy industry, with direct benefits for the quality and shelf life of dairy products.
\end{abstract}

Key words: cold microfiltration, carbon dioxide backpulsing, flux optimization, microbial removal

\footnotetext{
Received November 27, 2007.

Accepted May 29, 2008.

${ }^{1}$ Corresponding author: cim24@cornell.edu
}

\section{INTRODUCTION}

The quality and shelf life of dairy products depends greatly on the microbiological quality of raw milk. Gram-negative psychrotrophic bacteria, which are the predominant microflora in refrigerated raw milk, do not survive heat treatment. However, they produce heat-resistant extracellular proteases and lipases that, similar to spores and somatic cells, are not affected by the standard HTST pasteurization (Law, 1979; Cousin, 1982). High SCC can also lead to increased proteolytic and lipolytic activity in milk, compromising the quality and shelf life of dairy foods (Azzara and Dimick, 1985; Verdi and Barbano, 1988).

Membrane filtration has gained significant acceptance in the dairy industry in recent years, with one of its most common applications being the physical removal of microorganisms from milk by microfiltration (MF). Because the size of microorganisms present in milk $(0.2$ to $6 \mu \mathrm{m})$ overlaps with that of milk fat globules $(0.2$ to $15 \mu \mathrm{m})$, this process must be performed on skim milk (Saboya and Maubois, 2000). One of the benefits of $\mathrm{MF}$ is that, in addition to removing vegetative cells, it also removes spores and somatic cells from milk. Elwell and Barbano (2006) reported that a combination of MF and HTST pasteurization could significantly extend the microbial shelf life of fluid milk. In their study, a $3.79 \log$ reduction in total bacteria was achieved by $\mathrm{MF}$, and an additional $1.84 \log$ reduction was achieved by pasteurization. This resulted in a shelf life of $32 \mathrm{~d}$ with respect to proteolysis for the microfiltered and pasteurized fluid milk stored at $6.1^{\circ} \mathrm{C}$.

Microfiltration of milk is typically performed under warm conditions, at temperatures of 50 to $55^{\circ} \mathrm{C}$. The maximum benefits from MF could be obtained if the process were carried out during the early stages of milk processing, that is, in the raw milk stage. For milk to maintain its raw status according to the Pasteurized Milk Ordinance, the MF process would have to be conducted at temperatures lower than $45^{\circ} \mathrm{F}\left(6.7^{\circ} \mathrm{C}\right)$.

Running MF at low temperatures could also reduce the risk of thermophilic bacterial growth inside the membrane and the recirculation loop of the MF sys- 
tem. When $\mathrm{MF}$ is conducted at 50 to $55^{\circ} \mathrm{C}$, significant growth of thermophilic bacteria and germination of spores could occur in the membrane separation system. Thermophilic, spore-forming bacilli such as Bacillus stearothermophilus or Bacillus licheniformis found in milk and dairy products (Murphy et al., 1999; Hyde, 2002) can easily contaminate the processing equipment. For instance, thermophilic bacilli were found to grow within the regeneration sections of heat exchangers and in evaporators, which typically operate at temperatures of 45 to $75^{\circ} \mathrm{C}$ (Scott et al., 2007). These microorganisms are difficult to eliminate from the processing environment because of their resistance to the harsh chemical and temperature conditions of cleaning-in-place programs, their fast growth rate and wide temperature growth range, and their ability to form biofilms (Parkar et al., 2001; Scott et al., 2007). Biofilm formation is of particular concern, because bacteria living within biofilms may be 100 to 1,000 times less susceptible to sanitation techniques than those in a free-living state (Gilbert et al., 2002). In membrane separation systems, microbiological fouling of the membrane is particularly problematic. Kochkodan et al. (2006) reported that adsorption of even a few bacteria capable of division on a membrane surface resulted in microbial counts as high as $4.7 \times 10^{21} \mathrm{cfu}$ in $24 \mathrm{~h}$, under favorable growth conditions. Deposition and growth of bacteria on the membrane, and subsequent biofilm formation are favored by the low shear stress conditions at the membrane surface (Azevedo et al., 2006). The development of a cold MF process has the potential to minimize the risk of microbial fouling, which could be a significant benefit for the dairy industry.

The objective of this study was to design and optimize a cold cross-flow MF process that efficiently removes microorganisms, spores, and somatic cells from cold raw skim milk while yielding high permeate fluxes and keeping the chemical composition of the microfiltered milk unchanged.

\section{MATERIALS AND METHODS}

\section{MF Experiments}

The pilot-scale experimental MF setup consisted of a tubular ceramic membrane element of Tami design (GEA Filtration, WI) housed in a stainless steel housing, a tubular heat exchanger, and a variable-speed centrifugal pump (Figure 1). The membrane had a nominal pore size of $1.4 \mu \mathrm{m}$, an outside diameter of 25 $\mathrm{mm}$ and a total length of $1,200 \mathrm{~mm}, 23$ internal channels of $3.5-\mathrm{mm}$ hydraulic diameter each, and a total membrane area of $0.35 \mathrm{~m}^{2}$. Throughout the study, 4 identical membrane elements were used, referred to as membranes $1,2,3$, and 4 .

Cold, raw skim milk was obtained from the Cornell Dairy Plant (Ithaca, NY). The temperature of the milk during the cold MF was maintained at $6 \pm 1{ }^{\circ} \mathrm{C}$ by passing the milk through a countercurrent tubular heat exchanger (Figure 1), using chilled water as the cooling medium. For the warm MF runs, the temperature of the milk was $50^{\circ} \mathrm{C}$ and hot water was used as the heatexchange medium. Cross-flow velocities ranging from 5.0 to $7.0 \mathrm{~m} / \mathrm{s}$, and transmembrane pressures (TMP) in the range of 52 to $131 \mathrm{kPa}$ were tested. The crossflow velocity was changed by adjusting the flow rate of the centrifugal pump. Transmembrane pressure was calculated as TMP $=\left(\mathrm{P}_{1}+\mathrm{P}_{2}\right) / 2-\mathrm{P}_{\mathrm{p}}$, where $\mathrm{P}_{1}$ is feed inlet pressure, $\mathrm{P}_{2}$ is retentate outlet pressure, and $\mathrm{P}_{\mathrm{p}}$ is permeate pressure. The locations of the pressure gauges are indicated in Figure 1.

The experiments started with the pump at lowvelocity conditions, and once the water was flushed out of the system and skim milk was being collected, the pump was set to the desired flow rate. The target TMP was set by adjusting a butterfly valve placed on the retentate side of the operating system (valve 3 in Figure 1). The amount of permeate (M) was determined gravimetrically at regular time intervals (1 to $3 \mathrm{~min}$ ) by using an electronic scale.

The MF permeate flux (J) was then calculated according to the equation

$$
\mathrm{J}=\frac{\mathrm{M}}{\mathrm{A} \times t \times \rho},
$$

where $\mathrm{J}$ is the permeate flux $\left(\mathrm{L} / \mathrm{m}^{2} \mathrm{~h}\right)$; A is the membrane surface area $\left(\mathrm{m}^{2}\right) ; t$ is time (min); $\mathrm{M}$ is the permeate weight $(\mathrm{kg})$; and $\rho$ is the permeate density at the operating temperature $\left(\mathrm{kg} / \mathrm{m}^{3}\right)$.

The permeate density $(\rho)$ was determined by using a picnometer. The duration of the MF experiments was either $45 \mathrm{~min}$ or $3 \mathrm{~h}$. All experiments were performed in triplicate. Exceptions to this are clearly indicated in the text.

\section{$\mathrm{CO}_{2}$ Backpulsing System}

A gas backpulsing technique using carbon dioxide gas was developed and optimized. Carbon dioxide was injected through a port located on the permeate side close to the feed inlet port of the membrane (Figure 1), where maximum membrane fouling was expected. During the MF process, $\mathrm{CO}_{2}$ gas pulses, with a duration of 10 and $15 \mathrm{~s}$, were applied on the permeate side, at a gas pressure slightly exceeding the feed pressure 


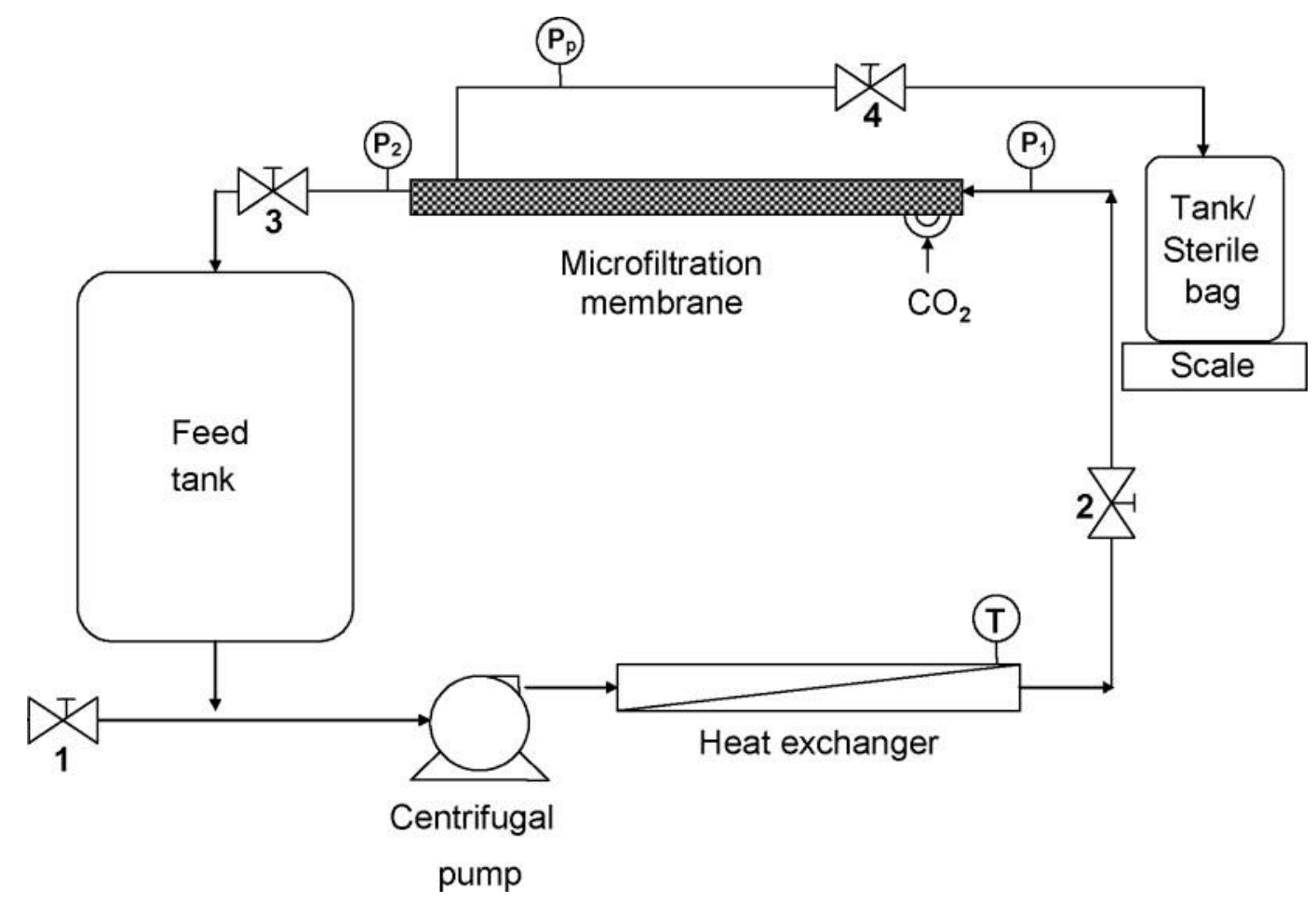

Figure 1. Diagram of the microfiltration experimental setup.

at the inlet of the membrane $\left(\mathrm{P}_{1}\right)$. The pulses were applied at time intervals of $30 \mathrm{~s}$ to $1 \mathrm{~min}$.

\section{Membrane Cleaning}

A complete chemical cleaning cycle was performed after each MF experiment. The cleaning protocol included a reverse osmosis (RO) water rinse, followed by alkaline cleaning with Ultrasil-25 at a $20 \mathrm{~g} / \mathrm{L}$ concentration at $t=85^{\circ} \mathrm{C}$ for $30 \mathrm{~min}$, a second $\mathrm{RO}$ water rinse until neutrality $(\mathrm{pH}=7)$, and a 15 -min acid cleaning using a $5 \mathrm{~mL} / \mathrm{L} \mathrm{HNO}_{3}$ solution at $t=50^{\circ} \mathrm{C}$. Between uses, the membrane was stored in $\mathrm{HNO}_{3}$ solution. The membrane was thoroughly rinsed with $\mathrm{RO}$ water before each experiment. In addition to the regular cleaning procedure, before each experiment that required collection of samples for microbial analyses, a hot $\mathrm{RO}$ water rinse at $t=80^{\circ} \mathrm{C}$ for 20 min was performed to kill any microorganisms that may have been present in the MF system.

The efficiency of cleaning and the change in the membrane performance with time was monitored by determining the water flux at $20^{\circ} \mathrm{C}$ of the cleaned membrane before every MF run. The water flux was determined by performing an MF run with RO water at a TMP of $69 \mathrm{kPa}$ and a velocity of $7 \mathrm{~m} / \mathrm{s}$. The amount of permeate collected over 3 min was measured gravimetrically and used to calculate the water flux by using equation [1]. The water flux measurements were performed in triplicate.

\section{Sampling for Microbiological and Chemical Analyses}

Microbiological tests were performed on both the raw skim milk (feed) and on the microfiltered skim milk (permeate). The permeate was aseptically collected by using a QMI aseptic collection system (QMI, St. Paul, MN), consisting of an aseptic collection elbow and aseptic collection bags of 2-L capacity. Samples for microbial tests were then aseptically transferred into sterile containers. All microbiological analyses were performed immediately after the MF experiments.

Samples for chemical analyses were collected in 4-oz. $(118 \mathrm{~mL})$ plastic vials. When chemical analyses could not be performed immediately, milk and permeate samples were frozen at $-80^{\circ} \mathrm{C}$ and kept frozen until they were analyzed. All chemical analyses were performed within a maximum of $2 \mathrm{wk}$ after the MF experiments.

\section{Microbiological Analyses}

Evaluation of Vegetative Bacteria. Ten milliliters of raw skim milk or permeate was aseptically drawn out of the collection containers and diluted in saline 
blanks when needed, followed by plating on standard methods agar medium (SMA medium; Fisher, Chicago, IL). The plates were incubated at $32^{\circ} \mathrm{C}$ for $48 \mathrm{~h}$. The standard plate count method was used to quantify the colony-forming units $(\mathrm{cfu} / \mathrm{mL})$ present in the raw skim milk and permeate.

Evaluation of Bacterial Spores. Before plating for spore quantification, the samples (raw skim milk or permeate) were heat-treated to inactivate all vegetative microflora. The procedure entailed the transfer of $10 \mathrm{~mL}$ of each sample to autoclaved screw-capped glass test tubes, including one control in which a thermometer was inserted to monitor the milk temperature during incubation. The tubes were placed in a shaker water bath at $80^{\circ} \mathrm{C}$. Once the milk or permeate temperature reached $80 \pm 1^{\circ} \mathrm{C}$, it was incubated for $12 \mathrm{~min}$ at that temperature to inactivate any viable microorganisms present. After $12 \mathrm{~min}$, the samples were removed from the water bath, placed immediately in an ice bath, and cooled to $4^{\circ} \mathrm{C}$. Quantification of the spores was then performed by plating, following the protocol described above. All microbiological analyses were performed in triplicate, and all platings were performed in duplicate.

\section{Somatic Cell Analyses}

Somatic cell counts were obtained by using a Fossomatic somatic cell counter at the DairyOne laboratory (Ithaca, NY). Twelve measurements were carried out for each sample, and the results are reported as thousands of somatic cells per milliliter of milk or permeate.

\section{Protein Analyses}

The feed (skim milk) and the MF permeate were analyzed for total N (TN; AOAC, 2003; method 991.20), and non-CN N content (Lynch et al., 1998) by using the Kjeldahl method. Crude protein and $\mathrm{CN}$ contents were calculated as $\mathrm{TN} \times 6.38$ and as $(\mathrm{TN}-\mathrm{NCN}) \times 6.38$, respectively. Casein as a percentage of $\mathrm{CP}(\mathbf{C N} \% \mathbf{C P})$ was calculated as $(\mathrm{CN} / \mathrm{CP}) \times 100 \%$. All protein analyses were performed in duplicate. Analysis of variance and Tukey's HSD (honestly statistical difference) statistical tests were used to determine significant differences between samples at $P<0.05$.

\section{Structural Analyses by Scanning Electron Microscopy}

Scanning electron microscopy was used to visualize both the structure of the membrane and the fouling layer formed as a result of MF. After a 450-min MF run performed at a TMP of $69 \mathrm{kPa}$ and a velocity of $7 \mathrm{~m} / \mathrm{s}$, the ceramic membrane was removed from its stainless steel housing and drained of milk. One end of the membrane was frozen by dipping it into liquid $\mathrm{N}$ and then freeze-fracturing it. Small pieces of membrane (approximately $5 \times 5 \mathrm{~mm}$ surface area) were obtained from both the inner channels and the outer channels of the membrane. Portions of the membrane were chemically cleaned in a beaker following the same cleaning protocol used for the regeneration of the membrane surface after the MF runs. To ensure effective cleaning, agitation of the membrane pieces in the cleaning solution was done with a magnetic stirrer. The chemically cleaned and fouled membrane pieces were freeze-dried overnight, then sputter coated with a 60:40 mixture of $\mathrm{Au}$ and Pd by using a Denton Vacuum Desk II Cold Sputter Etch Unit (Denton Vacuum, Moorestown, NJ). An exposure time of $30 \mathrm{~s}$ was used, which yielded approximately $10 \mathrm{~nm}$ of coating. The sputter-coated samples were then viewed with a Leica Stereoscan 440 scanning electron microscope (Leica Cambridge Ltd., Cambridge, UK) at the Cornell Center for Materials Research (Ithaca, NY).

\section{RESULTS AND DISCUSSION}

\section{Identification of Optimal Transmembrane Pressure and Cross-Flow Velocity}

During all MF experiments, the permeate flux followed a trend typical of membrane separation: a pronounced decline during the first minutes, followed by a slower but steady decline over time. The average results of 3 experimental runs indicated that, after 45 min of MF, a flux of $4.2 \mathrm{~L} /\left(\mathrm{m}^{2} \mathrm{~h}\right)$ was obtained at 5.0 $\mathrm{m} / \mathrm{s}$, a flux of $16.7 \mathrm{~L} /\left(\mathrm{m}^{2} \mathrm{~h}\right)$ was obtained at $6.0 \mathrm{~m} / \mathrm{s}$, and a flux of $40.5 \mathrm{~L} /\left(\mathrm{m}^{2} \mathrm{~h}\right)$ was obtained at $7.0 \mathrm{~m} / \mathrm{s}$ (Figure $2 a)$. In addition to the flux increase, another significant effect of high feed velocity was the less pronounced decline of flux with time, quantified by the change in flux relative to the initial flux $\left(\mathrm{J} / \mathrm{J}_{\mathrm{in}}\right.$; see Figure $\left.2 \mathrm{~b}\right)$. The initial flux $\left(\mathrm{J}_{\mathrm{in}}\right)$ was considered to be the flux obtained after the first $5 \mathrm{~min}$ of MF. This approach was taken to ensure that the permeate space was completely filled when flux measurements were taken. The greater flux values obtained when increasing the cross-flow velocity were probably due to the enhanced hydrodynamic effects at the membrane surface. The Reynolds number (Re) for the flow inside the membrane channels had values in the range of 5,000 to 7,000 when the velocity varied from 5 to $7 \mathrm{~m} / \mathrm{s}$, meaning that all MF runs were conducted in a fully developed turbulent regime. Turbulence and high shear are known to minimize the effects of concentration polarization and the develop- 
ment of a fouling layer, thus leading to greater permeate fluxes.

The effect of TMP on flux was then tested by performing MF experiments at the cross-flow velocity that yielded the greatest flux $(7 \mathrm{~m} / \mathrm{s})$ and the range of TMP values allowed by the experimental setup. In the regular experimental setup (setup 1), the permeate collection port was open to the atmosphere; thus, the permeate pressure $\left(\mathrm{P}_{\mathrm{p}}\right)$ equaled the atmospheric pressure. Transmembrane pressure was controlled by adjusting the pressure on the feed side $\left(\mathrm{P}_{1}\right)$, which allowed a range of TMP values from 69 to $131 \mathrm{kPa}$.

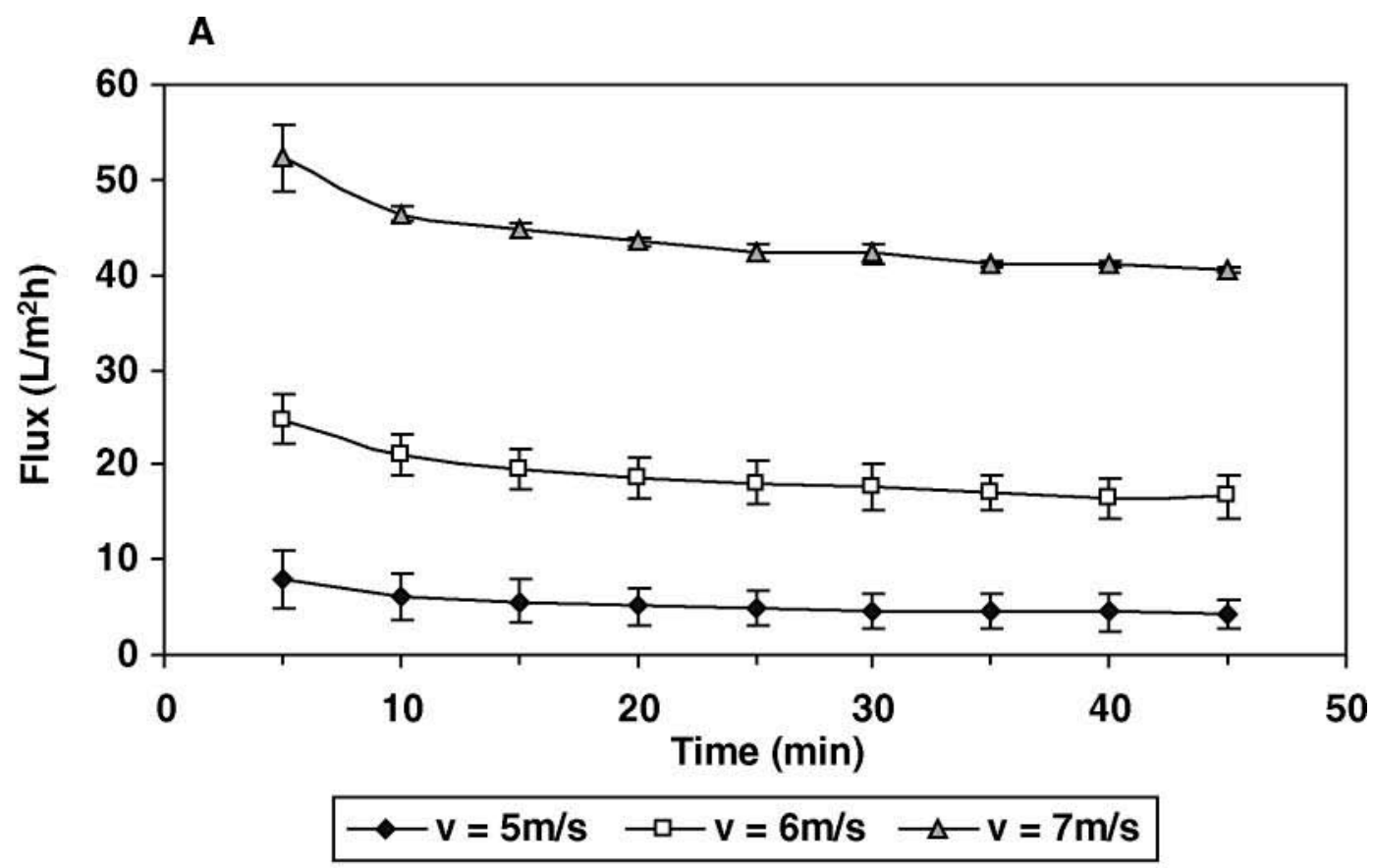

B

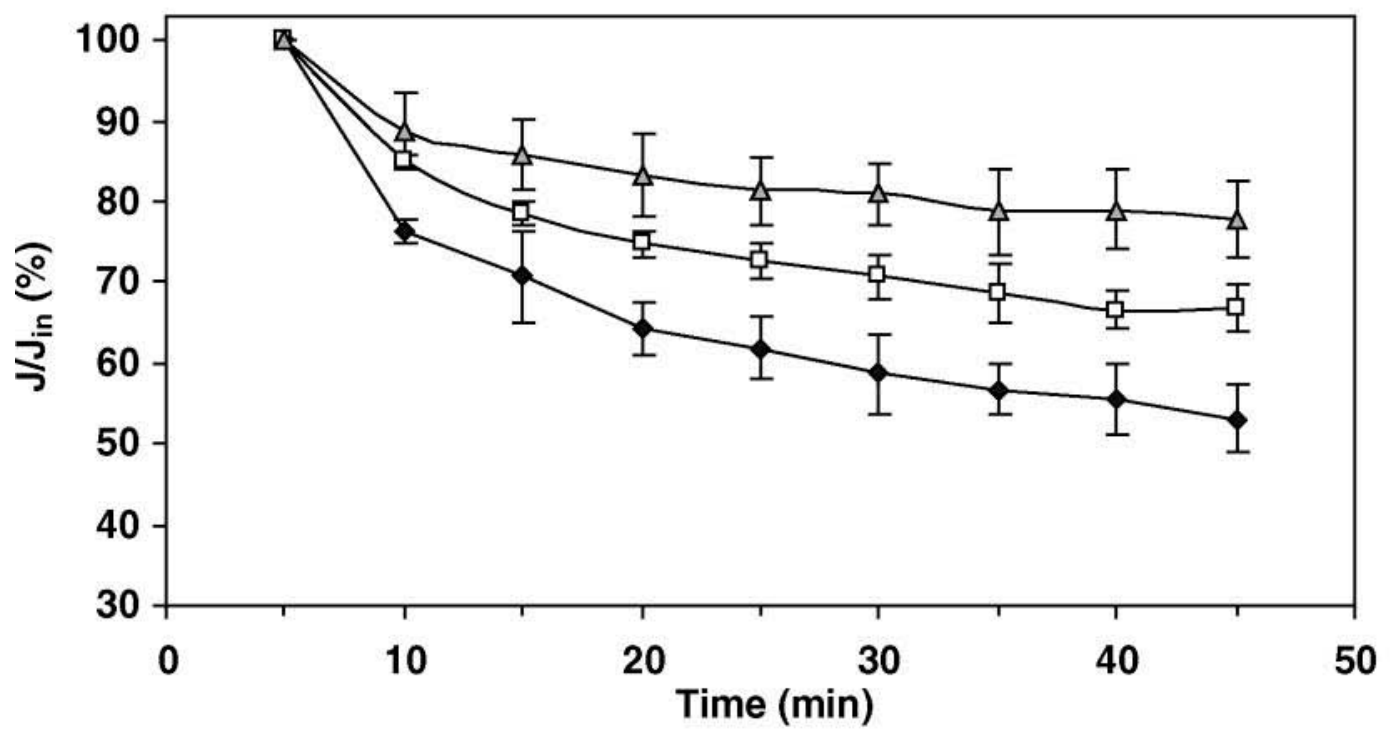

$\neg-v=5 \mathrm{~m} / \mathrm{s} \quad \square-v=6 \mathrm{~m} / \mathrm{s} \quad \triangle-v=7 \mathrm{~m} / \mathrm{s}$

Figure 2. Permeate flux (a) and relative flux change $\left(\mathrm{J} / \mathrm{J}_{\text {in }} ; \mathrm{b}\right)$ for cold microfiltration of raw skim milk under different cross-flow velocity (v) conditions. Error bars represent standard deviations. Transmembrane pressure $=69 \mathrm{kPa}$ and $t=6 \pm 1^{\circ} \mathrm{C}$. The water flux for these experiments was $987 \pm 104 \mathrm{~L} /\left(\mathrm{m}^{2} \mathrm{~h}\right)$. 
Among 3 replicate runs, after $45 \mathrm{~min}$ of $\mathrm{MF}$, an average flux of $6.7 \mathrm{~L} /\left(\mathrm{m}^{2} \mathrm{~h}\right)$ was obtained at a TMP of $131 \mathrm{kPa}$, whereas at a TMP of $69 \mathrm{kPa}$, an average flux of 40.5 $\mathrm{L} /\left(\mathrm{m}^{2} \mathrm{~h}\right)$ was achieved (Figure 3a). No significant differences in flux were observed between 69 and $81 \mathrm{kPa}$, creating a plateau in the flux versus TMP dependency. When TMP exceeded $81 \mathrm{kPa}$, the flux decreased significantly with the increase in TMP. Moreover, TMP in excess of $81 \mathrm{kPa}$ resulted in a much more pronounced flux decline as compared with the lower TMP values (Figure 3b).

To expand the range of TMP tested, a second experimental setup (setup 2) was designed, which included a $\mathrm{CO}_{2}$ pressurized tank for permeate collection. This allowed the permeate pressure $\left(\mathrm{P}_{\mathrm{p}}\right)$ to be controlled, which extended the range of achievable TMP to lower values. Figure $4 \mathrm{a}$ and $4 \mathrm{~b}$ illustrate the dynamics of flux and relative flux change for TMP from 52 to $76 \mathrm{kPa}$. In this TMP range, the lowest flux values were achieved at the lowest TMP $(52 \mathrm{kPa})$. For the other 4 TMP values, comparable fluxes were obtained (Figure 4a). The decrease in flux with time $\left(\mathrm{J} / \mathrm{J}_{\text {in }}\right)$ was the least pronounced at the lowest TMP tested $(52 \mathrm{kPa})$, as seen in Figure $4 \mathrm{~b}$. A direct comparison between the fluxes obtained with the 2 different sets of TMP experiments could not be made, both because of the different experimental settings and because of the use of 2 membranes, which had the same pore size but slightly different water flux values. Yet in both instances, a plateau was reached in the flux versus TMP curve, at TMP values slightly below and above $69 \mathrm{kPa}$ (Figure 5a). This allowed the use of the flux obtained at a TMP of $69 \mathrm{kPa}$ as a reference value for the 2 sets of experiments. A relative flux $\left(\mathrm{J}_{\mathrm{TMP}} / \mathrm{J}_{69} \mathrm{kPa}\right)$ was calculated and used to compare the results obtained at all TMP values directly.

The flux-TMP correlation shown in Figure 5b is consistent with the widely accepted critical flux theory, which states that 3 regimes of flux dependency on TMP can be distinguished in MF (Field et al., 1995; Howell, 1995; Brans et al., 2004). In regime I, at TMP below a critical pressure, fouling is insignificant and the process is characterized by optimal selectivity but by low values of the permeate flux. In regime II, in a TMP range just above the critical pressure, the flux reaches a limiting value, independent of TMP. This is the regime that is typically recommended for conducting $\mathrm{MF}$ for reduction of bacteria and spores or concentration of CN micelles, with the suggestion that a TMP value just above the critical pressure in the lower part of regime II should be chosen (Brans et al., 2004). A high cross-flow velocity is considered advantageous for the process in this range, because it can increase the flux value attributable to hydrodynamic effects. In regime III, at TMP above the critical pressure, pronounced fouling layer formation and compaction take place, which result in lower, time-dependent fluxes and reduced selectivity. This TMP range should be avoided in membrane processing.

In this study, TMP values of up to approximately $60 \mathrm{kPa}$ seemed to correspond to regime I, TMP values of $60 \mathrm{kPa}$ to $85 \mathrm{kPa}$ defined the critical TMP regime (regime II), and TMP greater than approximately 85 $\mathrm{kPa}$ corresponded to regime III. For TMP $>85 \mathrm{kPa}$, the more pronounced reduction of the flux at $45 \mathrm{~min}$ with increasing TMP (the dotted line in Figure 5b) as compared to the reduction of the initial flux (the solid line in Figure 5b) indicates a compaction of the fouling layer characteristic of regime III.

On the basis of the above observations, we concluded that a TMP of 60 to $85 \mathrm{kPa}$ and a velocity of $7 \mathrm{~m} / \mathrm{s}$ are conducive to maximum permeate flux in the cold $\mathrm{MF}$ of skim milk when using a membrane of $1.4-\mu \mathrm{m}$ pore size. This is consistent with previous reports in the literature, which suggest that favorable conditions for MF include moderate transmembrane pressure and high cross-flow velocity (Pafylias et al., 1996; Brans et al., 2004). It must be noted that in this study $7 \mathrm{~m} / \mathrm{s}$ was the greatest cross-flow velocity tested, and that additional benefits might be obtained at greater velocities, yet this value of cross-flow velocity is consistent with the one reported by Saboya and Maubois (2000) for warm milk MF.

In addition to operation under optimal process parameters, another critical aspect for membrane separation is maintaining a constant membrane performance for a long period of time. Even under optimal process conditions, membrane fouling still occurs. One way to monitor the degree of fouling of a membrane is by evaluating its water flux. As seen in Figure 6, there is a direct dependence of the permeate flux on the water flux. The decrease in water flux with time is caused by irreversible, in-depth membrane fouling, which occurs because of suboptimal operation of the process, insufficient cleaning, or simply extended membrane use. This type of fouling negatively affects both the flux and membrane selectivity. To avoid any significant influences of the water flux on the results of the study, in this work each set of experiments was performed under similar water flux conditions. Across the entire study, a membrane water flux of approximately $1,000 \pm 100$ $\mathrm{L} /\left(\mathrm{m}^{2} \mathrm{~h}\right)$ was maintained.

\section{Efficiency of the Cold MF Process for the Removal of Microorganisms and Somatic Cells from Skim Milk}

The efficiency of the cold MF process $\left(t=6 \pm 1^{\circ} \mathrm{C}\right)$ for the physical removal of bacteria, spores, and somatic cells was assessed for a range of MF experiments per- 


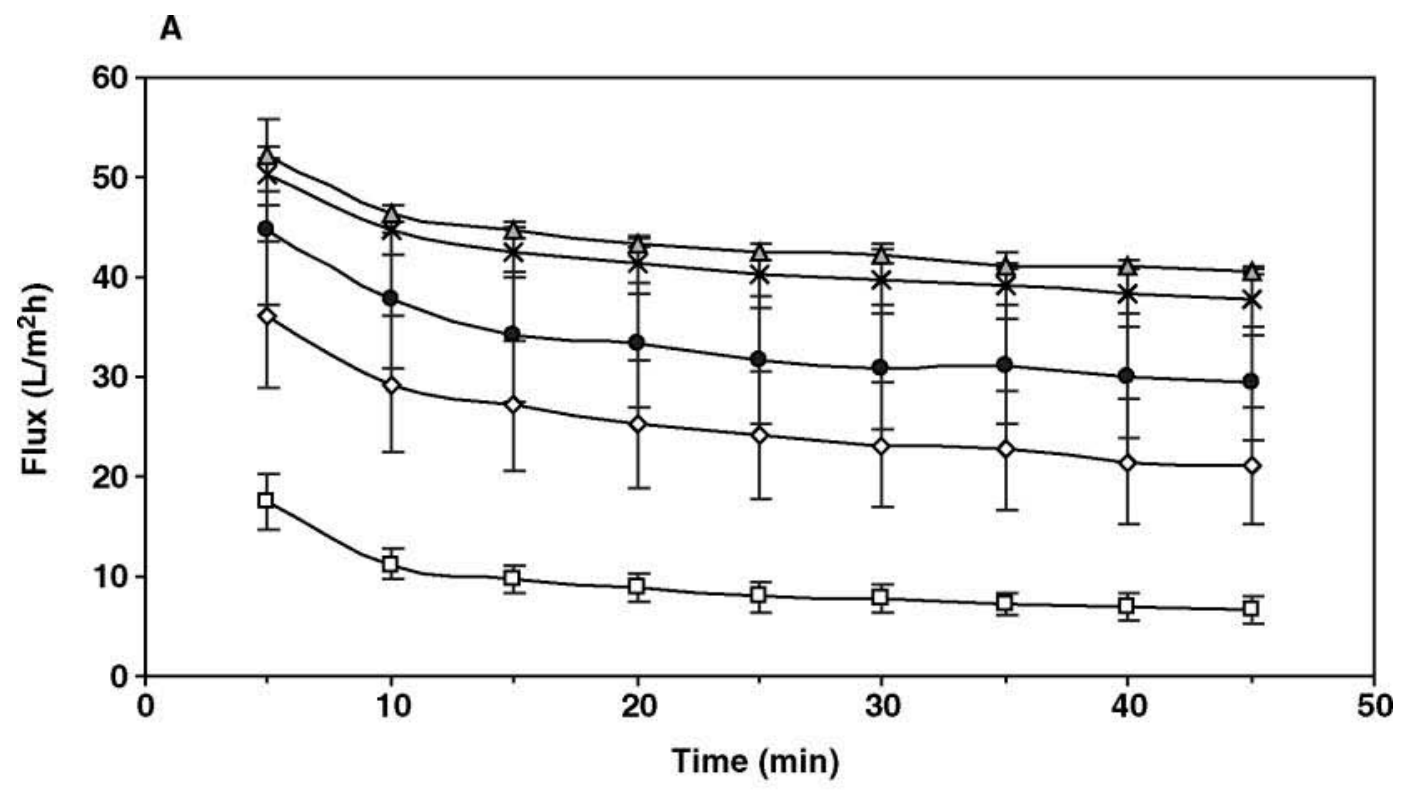

$$
\begin{aligned}
& \neg-\mathrm{TMP}=69 \mathrm{kPa} \quad \rightarrow-T M P=83 \mathrm{kPa} \quad \longrightarrow \text { TMP }=93 \mathrm{kPa} \\
& \leadsto-\mathrm{TMP}=110 \mathrm{kPa} \quad-\square-\mathrm{TMP}=131 \mathrm{kPa}
\end{aligned}
$$

B

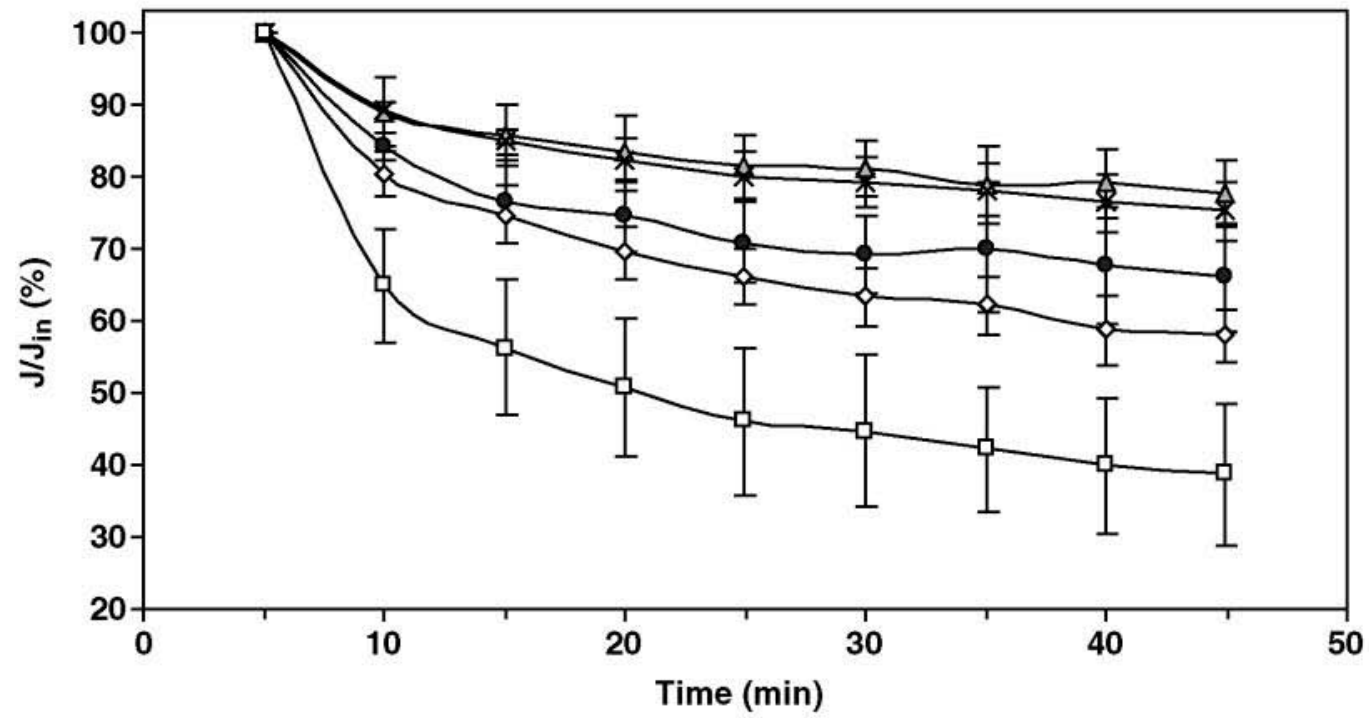

$$
\begin{array}{ll}
\multimap-\mathrm{TMP}=69 \mathrm{kPa} & \rightarrow-T M P=83 \mathrm{kPa} \\
\curvearrowleft-\mathrm{TMP}=110 \mathrm{kPa} & \multimap-\mathrm{TMP}=131 \mathrm{kPa}
\end{array}
$$

$\rightarrow-T M P=93 \mathrm{kPa}$

Figure 3. Permeate flux (a) and relative flux change $\left(\mathrm{J} / \mathrm{J}_{\mathrm{in}} ; \mathrm{b}\right)$ for cold microfiltration of raw skim milk under different transmembrane pressure (TMP) conditions, at a constant cross-flow velocity of $7 \mathrm{~m} / \mathrm{s}$ and $t=6 \pm 1^{\circ} \mathrm{C}$. Error bars represent standard deviations. Water flux range: $1,079 \pm 101 \mathrm{~L} /\left(\mathrm{m}^{2} \mathrm{~h}\right)$.

formed under optimal processing conditions (velocity $=$ $7 \mathrm{~m} / \mathrm{s}, \mathrm{TMP}=69 \mathrm{kPa}$ ). The raw skim milk used in this study had a microbial load in the range of 3.61 to 5.25 $\log \mathrm{cfu} / \mathrm{mL}$ (Table 1 ). No microorganisms were identi- fied in the permeate samples by standard plate counting, suggesting complete or nearly complete removal of vegetative bacteria from skim milk as a result of MF. Spores and somatic cells were also effectively removed 

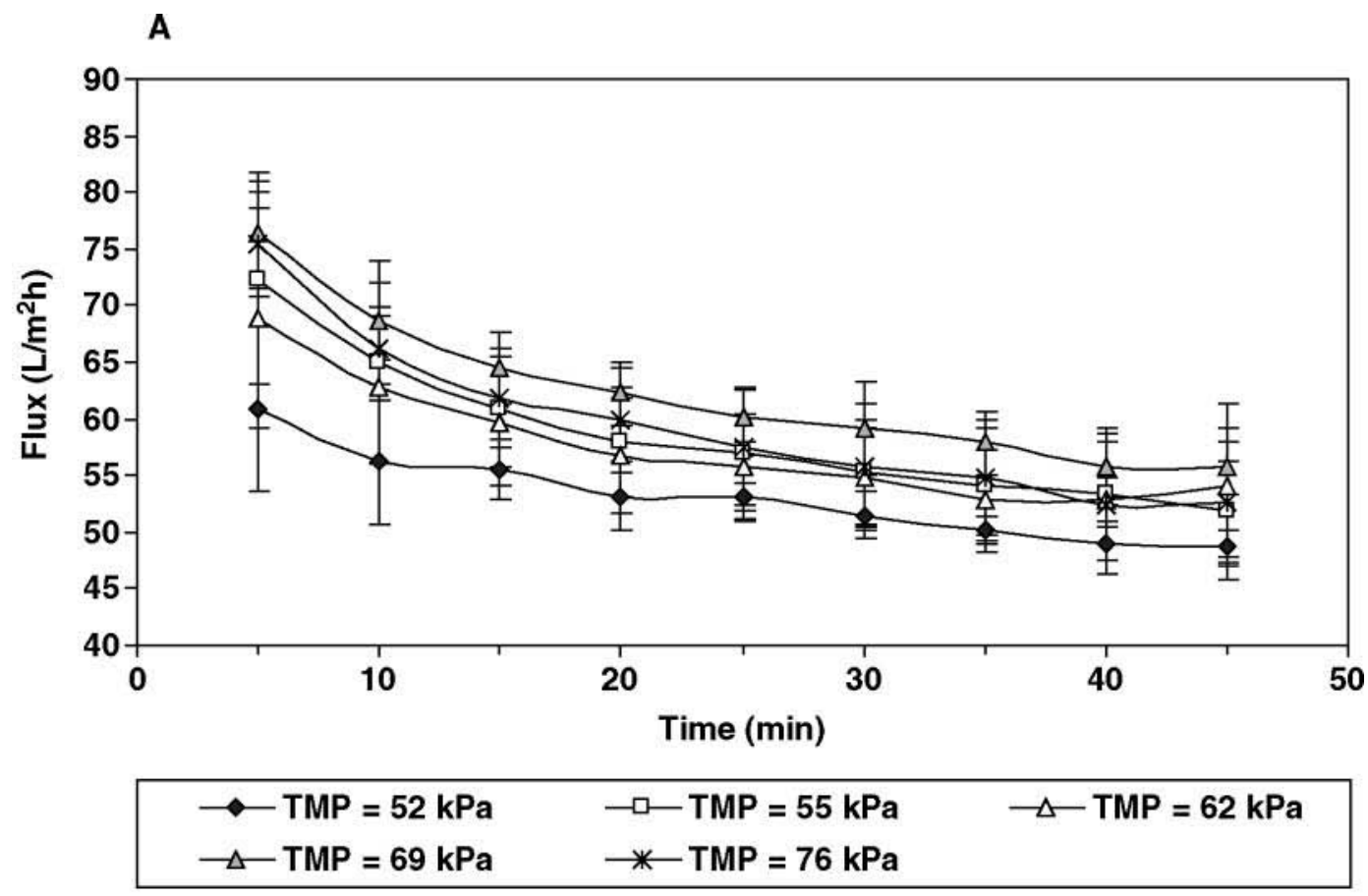

B

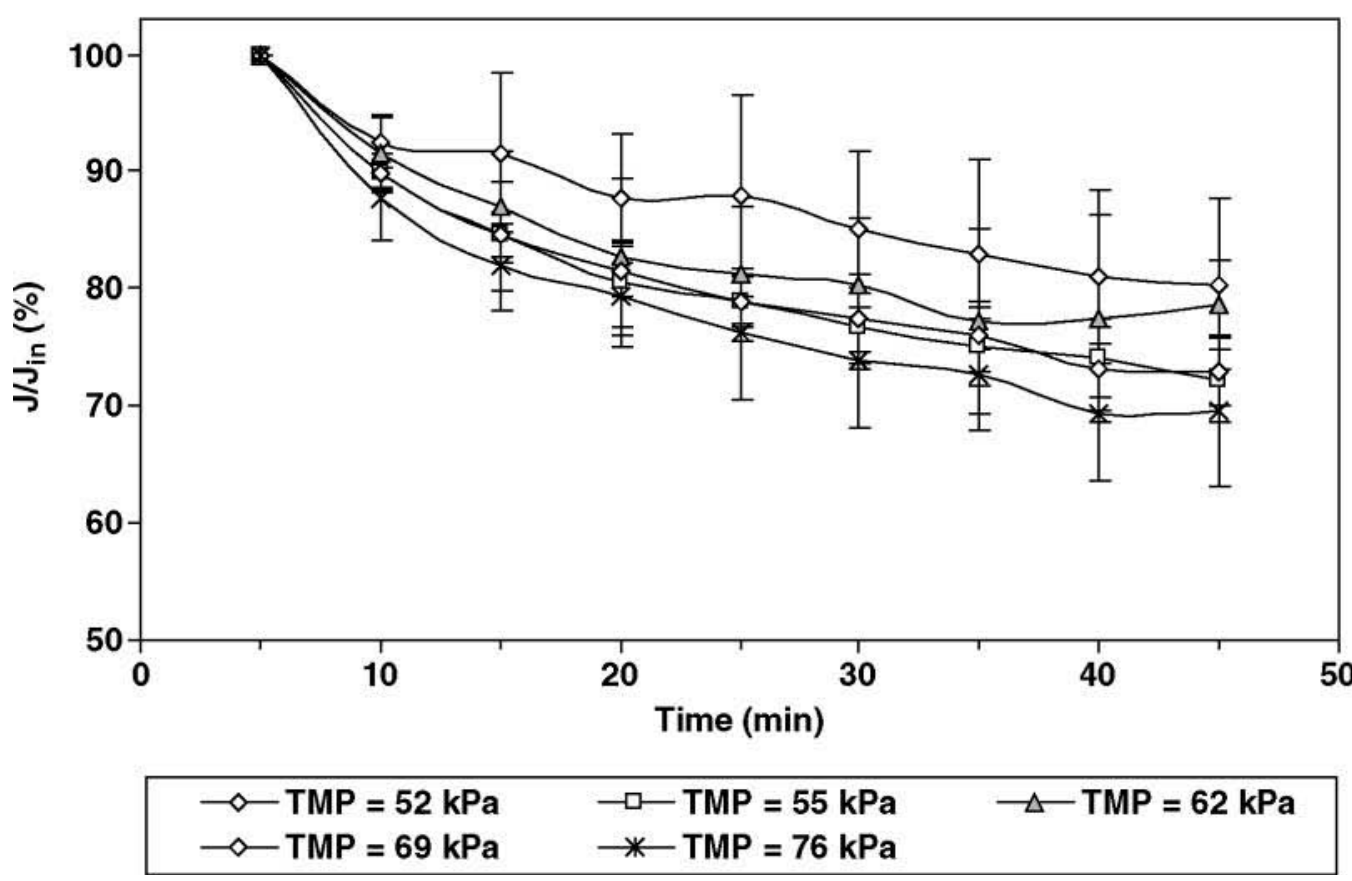

Figure 4. Permeate flux (a) and relative flux change $\left(\mathrm{J} / \mathrm{J}_{\mathrm{in}} ; \mathrm{b}\right)$ for cold microfiltration of raw skim milk under different transmembrane pressure (TMP) conditions, at a constant cross-flow velocity of $7 \mathrm{~m} / \mathrm{s}$ and $t=6 \pm 1^{\circ} \mathrm{C}$ for setup $2\left(\mathrm{CO}_{2}\right.$ counterpressure). Error bars represent standard deviations. The water flux for these experiments was $1,130 \pm 110 \mathrm{~L} /\left(\mathrm{m}^{2} \mathrm{~h}\right)$. For a TMP of $52 \mathrm{kPa}$, only 2 replicate measurements were performed.

from the raw skim milk by cold MF under optimal process conditions, as shown in Table 2 and Figure 7, respectively. The large variability in the somatic cell data for permeate (see Figure 7) is because most of the analyzed permeate samples from the 3 replicate runs did not contain any somatic cells. Only 1 in 19 samples was found positive for run A, 3 positives in 15 samples were found for run $\mathrm{B}$, and 2 positives in 15 samples 

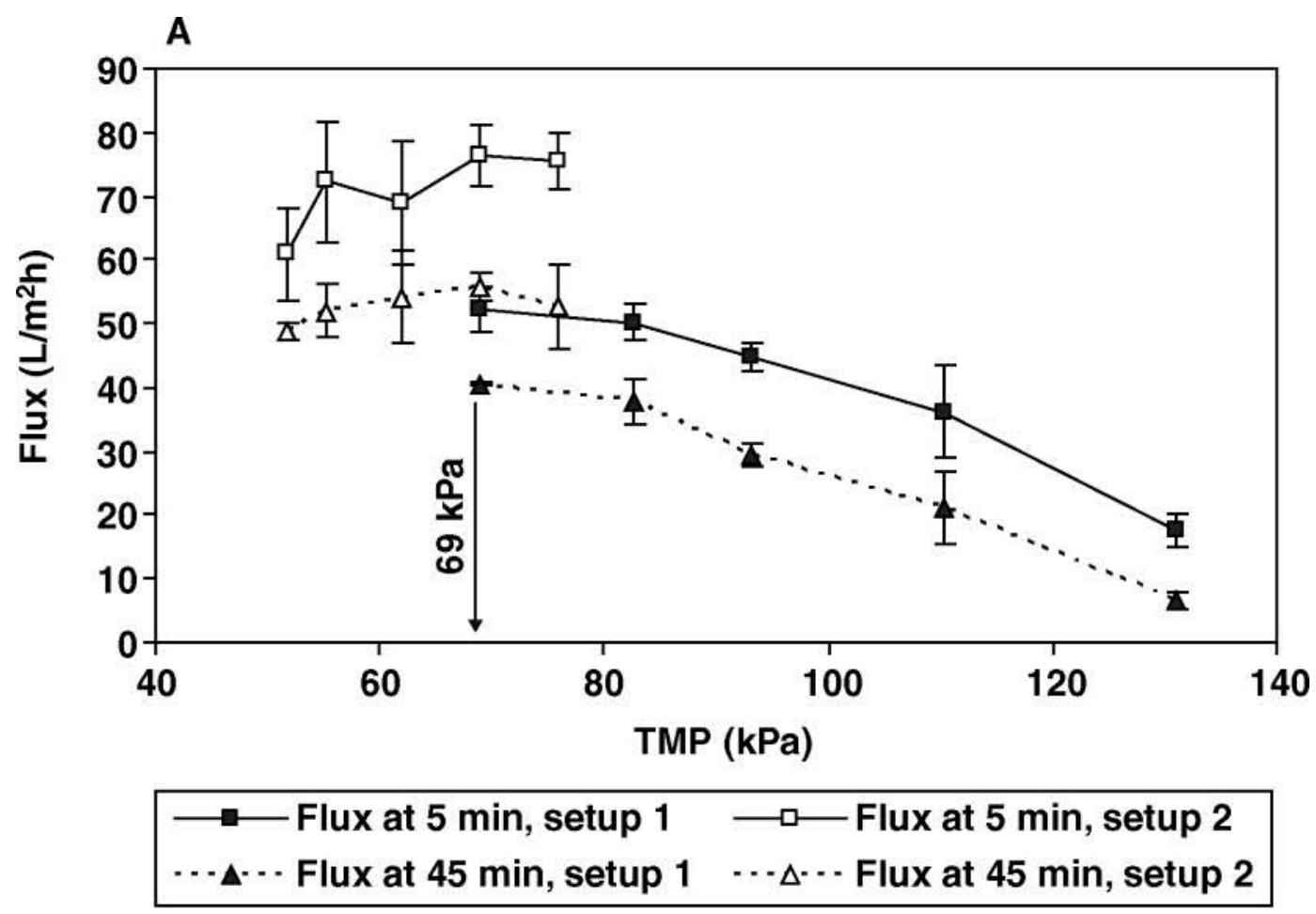

B

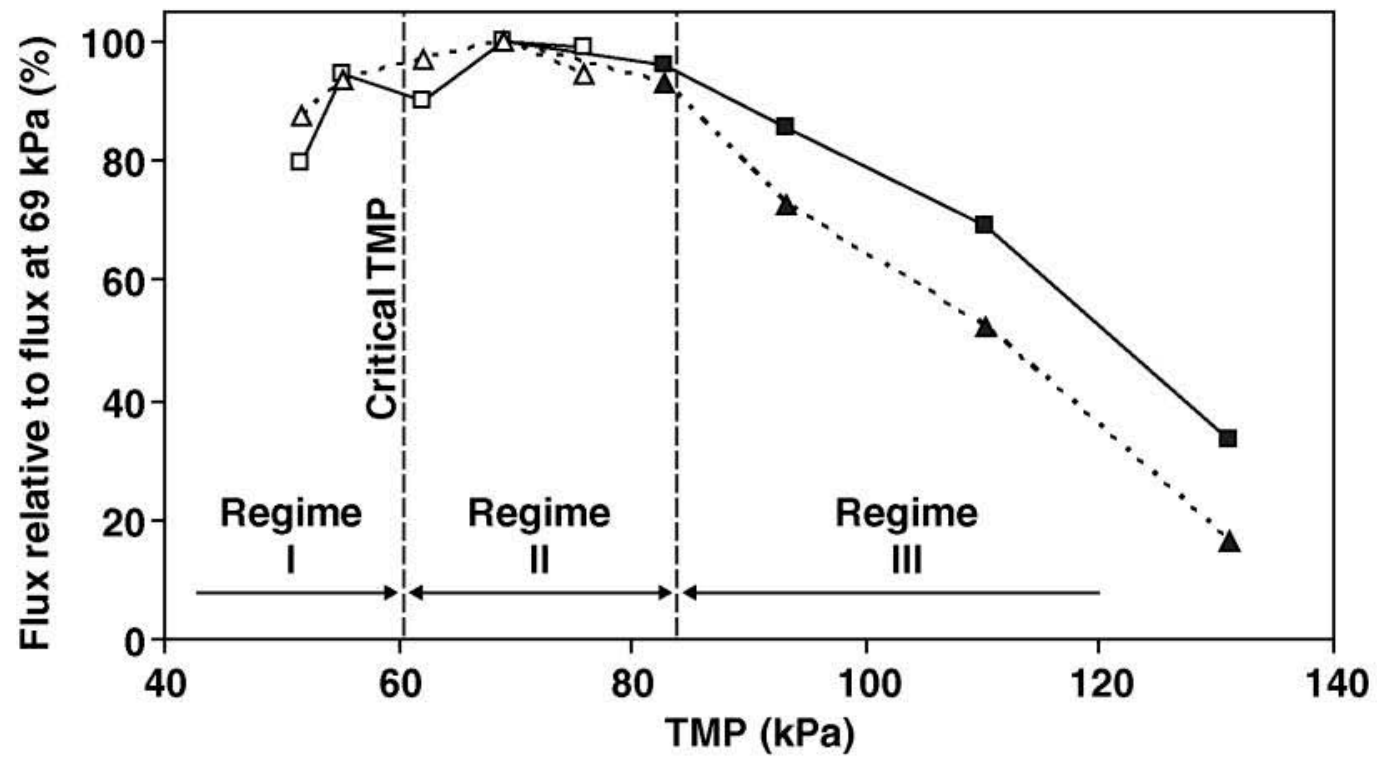

$\longrightarrow-$ Flux at $5 \mathrm{~min}$, setup $1-\square-$ Flux at $5 \mathrm{~min}$, setup 2

Figure 5. Absolute values of the (a) flux and (b) flux relative to the flux obtained at a transmembrane pressure (TMP) of $69 \mathrm{kPa}$ for microfiltration experiments carried out at different TMP, at a velocity of $7 \mathrm{~m} / \mathrm{s}$ and $t=6 \pm 1^{\circ} \mathrm{C}$. Error bars represent standard deviations. Closed symbols represent data obtained with setup 1 [membrane 2 ; water flux $=1,079 \pm 101 \mathrm{~L} /\left(\mathrm{m}^{2} \mathrm{~h}\right)$ ], and open symbols represent data obtained with setup 2 [membrane 3; water flux $\left.=1,130 \pm 110 \mathrm{~L} /\left(\mathrm{m}^{2} \mathrm{~h}\right)\right]$. 
Table 1. Reduction of microbial load (vegetative bacteria) in skim milk by cold microfiltration $(\mathrm{MF})^{1}$

\begin{tabular}{lcc}
\hline & \multicolumn{2}{c}{ Vegetative bacteria plate count (log cfu/mL) } \\
\cline { 2 - 3 } Experimental run & Raw skim milk & MF permeate \\
\hline 1 (membrane 1) & $5.25 \pm 0.30$ & $\mathrm{ND}^{2}$ \\
2 (membrane 3) & $4.62 \pm 0.20$ & $\mathrm{ND}$ \\
3 (membrane 4) & $3.61 \pm 0.07$ & $\mathrm{ND}$ \\
4 (membrane 4) & $3.83 \pm 0.12$ & $\mathrm{ND}$ \\
\hline
\end{tabular}

${ }^{1}$ Processing parameters: membrane pore size $=1.4 \mu \mathrm{m} ; t=6 \pm 1^{\circ} \mathrm{C}$; velocity $=7 \mathrm{~m} / \mathrm{s}$; transmembrane pressure $=69 \mathrm{kPa}$.

${ }^{2} \mathrm{ND}=$ none detected

were found for run C. All positives had counts of 1,000 somatic cells $/ \mathrm{mL}$.

Overall, we concluded that significant microbial and somatic cell reduction in raw skim milk was achieved with the cold MF process, which shows the potential of this process for improving the shelf life and quality of dairy foods. Spore and somatic cell removal is particularly important, because they are not destroyed by HTST pasteurization.

\section{Effect of MF on the Chemical Composition of the Microfiltered Skim Milk}

When using MF for microbial removal, protein retention by the membrane is the greatest concern in terms of depleting the milk of its native components.
Table 2. Reduction of spores in skim milk by cold microfiltration $(\mathrm{MF})^{1}$

\begin{tabular}{lcc}
\hline & \multicolumn{2}{c}{ Spore count $(\mathrm{log} \mathrm{cfu} / \mathrm{mL})$} \\
\cline { 2 - 3 } Experimental run & Raw skim milk & MF permeate \\
\hline Regime I (membrane 3) & $2.08 \pm 0.12$ & $\mathrm{ND}^{2}$ \\
Regime II (membrane 3) & $2.15 \pm 0.10$ & $\mathrm{ND}$ \\
\hline${ }^{1}$ Processing parameters: membrane pore size: $1.4 \mu \mathrm{m} ; t=6 \pm 1^{\circ} \mathrm{C} ;$ \\
velocity = $7 \mathrm{~m} / \mathrm{s}$; transmembrane pressure $=69 \mathrm{kPa}$. \\
${ }^{2} \mathrm{ND}=$ none detected.
\end{tabular}

As seen in Tables 3 and 4, low cross-flow velocity and high TMP, which were conducive to low fluxes, caused a significant reduction in the protein content of the MF milk. Under optimal processing conditions (velocity $=$ $7 \mathrm{~m} / \mathrm{s}$ and TMP $=69 \mathrm{kPa}$ ), the protein composition of the permeate (MF milk) was very close to that of the feed (skim milk). In addition to the transmission of all proteins by the membrane, the transmission of $\mathrm{CN}$ was monitored. As seen in Tables 3 and 4, the transmission of $\mathrm{CN}$ into the permeate was, in all cases, lower than the transmission of $\mathrm{CP}$, suggesting a preferential retention of $\mathrm{CN}$ by the membrane as compared with serum proteins. This preferential retention was rather small $(<1 \%)$ in most cases, with the exception of the lowest cross-flow velocity $(5 \mathrm{~m} / \mathrm{s})$, for which a relatively large decrease (4.41\%) was found in the $\mathrm{CN}$ to $\mathrm{CP}$ ratio in permeate as compared with the feed.

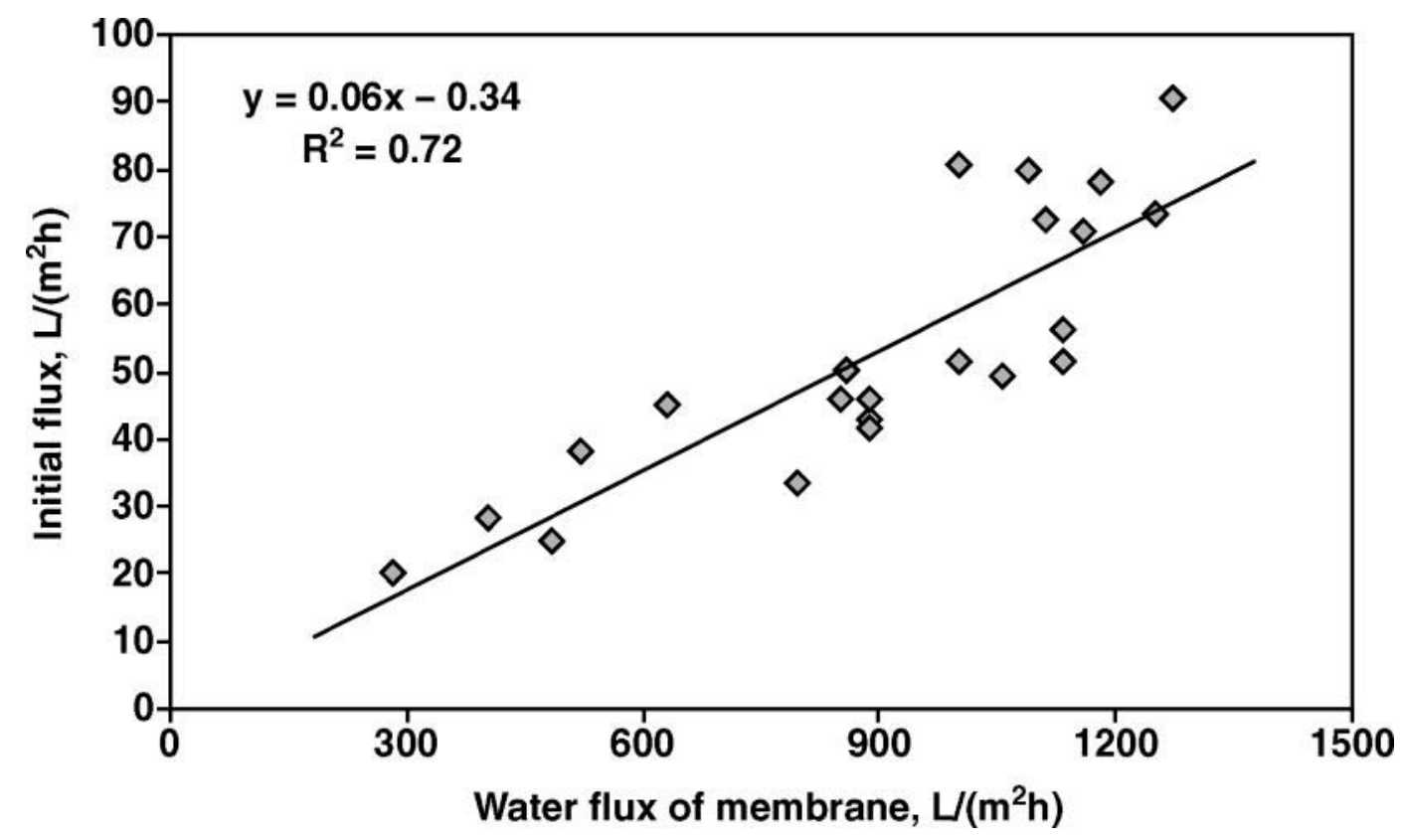

Figure 6. Effect of water flux on the initial permeate flux $\left(\mathrm{J}_{\mathrm{in}}\right)$ in the cold microfiltration $(\mathrm{MF})$ of skim milk. All MF experiments were performed with setup 1 (membranes 1 through 4 ), under optimal processing conditions: velocity $=7 \mathrm{~m} / \mathrm{s}$, transmembrane pressure in the critical pressure range (69 to $83 \mathrm{kPa})$, and $t=6 \pm 1^{\circ} \mathrm{C}$. All data points represent single MF experiments. 


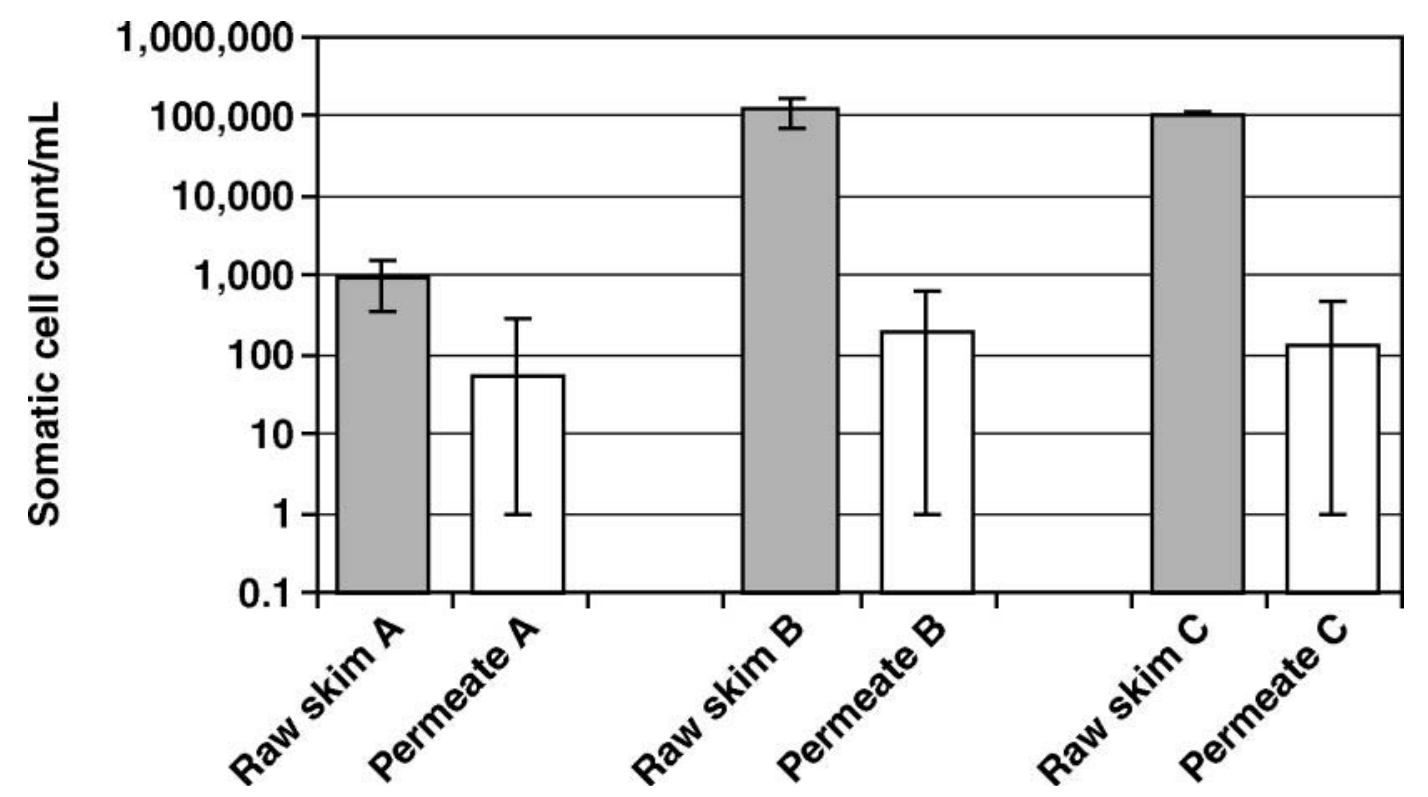

Figure 7. Effect of microfiltration on the SCC of skim milk. Processing conditions: $t=6 \pm 1^{\circ} \mathrm{C}$, velocity $=7 \mathrm{~m} / \mathrm{s}$, transmembrane pressure $=69 \mathrm{kPa}$. Run A: membrane 1; runs B and C: membrane 4. A minimum of 10 replicate measurements per sample were performed. Error bars represent standard deviations.

Figure 8 illustrates the clear correlation between protein retention and flux. This result demonstrates that it is absolutely critical to conduct the MF process under optimal conditions, which allow both a high flux and good transmission of proteins into the permeate while efficiently removing the microflora and somatic cells from the skim milk.

\section{Development of a $\mathrm{CO}_{2}$ Backpulsing Technique for Flux Enhancement}

Even under optimal process conditions, the permeate flux obtained in cold MF was considerably lower than that in the warm process (Figure 9). An initial flux of approximately $350 \mathrm{~L} /\left(\mathrm{m}^{2} \mathrm{~h}\right)$ was obtained at $53^{\circ} \mathrm{C}$ as compared with approximately $50 \mathrm{~L} /\left(\mathrm{m}^{2} \mathrm{~h}\right)$ at $6^{\circ} \mathrm{C}$. The flux values for the warm process were similar to those reported by Saboya and Maubois (2000). The main reason for this difference is believed to be the greater viscosity of milk and of the fouling layer under the lowtemperature conditions.

For cold MF to be economically viable, further technical solutions for flux enhancement need to be identified. Development of such solutions requires a detailed analysis of the factors that limit the flux, particularly fouling. In membrane separation, the significant pressure drop along the membrane causes TMP to decrease significantly from the inlet to the outlet. This results in uneven fouling-more pronounced at the inlet than at the outlet-and thus uneven separation performance along the membrane. A solution that is sometimes used to counteract this problem is the uniform TMP concept (Brans et al., 2004). Although uniform TMP can minimize fouling, its main drawback is the greater energy demand that results from setting up a crossflow on both sides of the membrane.

Another source of nonuniform fouling is the fluid velocity profile inside the membrane. The reported crossflow velocity is an average value, calculated based on the flow rate and the cross-section of the flow channels. In reality, the inside of each flow channel has a parabolic profile, with values ranging from a minimum in positions adjacent to the wall to a maximum in the center of the channel. In a multitubular membrane such as the one used in this study, the velocity profile is complicated by the fact that each of the channels has its own parabolic flow pattern. Therefore, the actual velocity inside the membrane channels varies greatly, depending both on the position of the channel and on the position inside each flow channel. The practical implication of this distribution is an uneven buildup of the fouling layer, which is expected to be minimal in the center of the membrane cross-section and maximum at the extreme axial position of the peripheral channels (Figure 10a). This hypothesis was visually confirmed by using scanning electron microscopy (Figure 10b). A much thicker layer of fouling material was observed on the surface of the outer channel (right) as compared to the surface of the inner channel (middle). These micrographs can be considered visual confirmation of the 
Table 3. Changes in the protein content of skim milk as a result of microfiltration (MF) at $t=6 \pm 1^{\circ} \mathrm{C}$, a transmembrane pressure of $69 \mathrm{kPa}$ and different cross-flow velocities

\begin{tabular}{|c|c|c|c|c|c|c|c|c|c|c|c|}
\hline \multirow{2}{*}{$\begin{array}{l}\text { Velocity } \\
(\mathrm{m} / \mathrm{s})\end{array}$} & \multicolumn{2}{|c|}{ CP (\%) } & \multirow{2}{*}{$\begin{array}{c}\mathrm{CP} \\
\text { transmission } \\
\text { in permeate } \\
(\%)\end{array}$} & \multicolumn{2}{|c|}{$\mathrm{NCN}^{1}(\%)$} & \multicolumn{2}{|c|}{$\mathrm{CN}(\%)$} & \multirow{2}{*}{$\begin{array}{c}\mathrm{CN} \\
\text { transmission } \\
\text { in permeate } \\
(\%)\end{array}$} & \multicolumn{2}{|c|}{$\mathrm{CN} \% \mathrm{CP}^{2}$} & \multirow{2}{*}{$\begin{array}{c}\text { Decrease } \\
\text { in } \mathrm{CN} \% \mathrm{CH} \\
\text { after } \mathrm{MF} \\
(\%)\end{array}$} \\
\hline & Feed & Permeate & & Feed & Permeate & Feed & Permeate & & Feed & Permeate & \\
\hline 5 & $3.09 \pm 0.006^{\mathrm{a}}$ & $2.23 \pm 0.005^{\mathrm{c}}$ & 72.17 & $0.738 \pm 0.0018^{\mathrm{m}}$ & $0.631 \pm 0.0042^{\circ}$ & 2.35 & 1.60 & 67.99 & 76.14 & 71.73 & 4.41 \\
\hline 6 & $3.09 \pm 0.006^{\mathrm{a}}$ & $2.85 \pm 0.000^{\mathrm{d}}$ & 92.04 & $0.738 \pm 0.0018^{\mathrm{m}}$ & $0.698 \pm 0.0146^{\mathrm{p}}$ & 2.35 & 2.15 & 91.22 & 76.14 & 75.47 & $<1$ \\
\hline 7 & $3.26 \pm 0.007^{\mathrm{b}}$ & $3.18 \pm 0.016^{\mathrm{e}}$ & 97.55 & $0.815 \pm 0.0012^{\mathrm{n}}$ & $0.826 \pm 0.0061^{\mathrm{m}}$ & 2.45 & 2.36 & 96.29 & 75.03 & 74.06 & $<1$ \\
\hline
\end{tabular}

${ }^{\mathrm{a}-\mathrm{e}}$ For CP data, different letters indicate statistically significant differences.

${ }^{\mathrm{m}-\mathrm{p}}$ For NCN data, different letters indicate statistically significant differences.

${ }^{1} \mathrm{NCN}=$ non- $\mathrm{CN} \mathrm{N}$.

${ }^{2}$ Casein as a percentage of $\mathrm{CP}$.

Table 4. Changes in the protein content of skim milk as a result of microfiltration (MF) at $t=6 \pm 1^{\circ} \mathrm{C}$, a cross-flow velocity of $7 \mathrm{~m} / \mathrm{s}$ and different transmembrane pressure (TMP) values

\begin{tabular}{|c|c|c|c|c|c|c|c|c|c|c|c|}
\hline \multirow{2}{*}{$\begin{array}{l}\text { TMP } \\
(\mathrm{kPa})\end{array}$} & \multicolumn{2}{|c|}{ CP (\%) } & \multirow{2}{*}{$\begin{array}{c}\mathrm{CP} \\
\text { transmission } \\
\text { in permeate } \\
(\%)\end{array}$} & \multicolumn{2}{|c|}{$\mathrm{NCN}^{1}(\%)$} & \multicolumn{2}{|c|}{ CN (\%) } & \multirow{2}{*}{$\begin{array}{c}\mathrm{CN} \\
\text { transmission } \\
\text { in permeate } \\
(\%)\end{array}$} & \multicolumn{2}{|c|}{$\mathrm{CN} \% \mathrm{CP}^{2}$} & \multirow{2}{*}{$\begin{array}{c}\text { Decrease } \\
\text { in CN\%CP } \\
\text { after MF } \\
(\%)\end{array}$} \\
\hline & Feed & Permeate & & Feed & Permeate & Feed & Permeate & & Feed & Permeate & \\
\hline 69 & $3.26 \pm 0.007^{\mathrm{a}}$ & $3.18 \pm 0.016^{\mathrm{c}}$ & 97.55 & $0.815 \pm 0.0012^{\mathrm{m}}$ & $0.826 \pm 0.0061^{\mathrm{m}}$ & 2.45 & 2.36 & 96.29 & 75.03 & 74.06 & $<1$ \\
\hline 83 & $3.26 \pm 0.007^{\mathrm{a}}$ & $3.17 \pm 0.003^{\mathrm{cd}}$ & 97.26 & $0.815 \pm 0.0012^{\mathrm{m}}$ & $0.813 \pm 0.0003^{\mathrm{m}}$ & 2.45 & 2.36 & 96.44 & 75.03 & 74.39 & $<1$ \\
\hline 110 & $3.26 \pm 0.007^{\mathrm{a}}$ & $3.08 \pm 0.000^{\mathrm{e}}$ & 94.32 & $0.815 \pm 0.0012^{\mathrm{m}}$ & $0.787 \pm 0.0001^{\mathrm{n}}$ & 2.45 & 2.29 & 93.54 & 75.03 & 74.41 & $<1$ \\
\hline 131 & $3.34 \pm 0.005^{\mathrm{b}}$ & $2.91 \pm 0.012^{\mathrm{f}}$ & 87.16 & $0.824 \pm 0.0093^{\mathrm{m}}$ & $0.725 \pm 0.0030^{\circ}$ & 2.51 & 2.18 & 86.88 & 75.32 & 75.08 & $<1$ \\
\hline
\end{tabular}

$\stackrel{\varrho}{\Phi}$. ${ }^{\mathrm{a}-\mathrm{f}}$ For CP data, different letters indicate statistically significant differences.

${ }^{\mathrm{m}-\mathrm{o}}$ For NCN data, different letters indicate statistically significant differences.

ㅇ $\quad{ }^{1} \mathrm{NCN}=$ non- $\mathrm{CN} \mathrm{N}$.

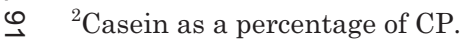




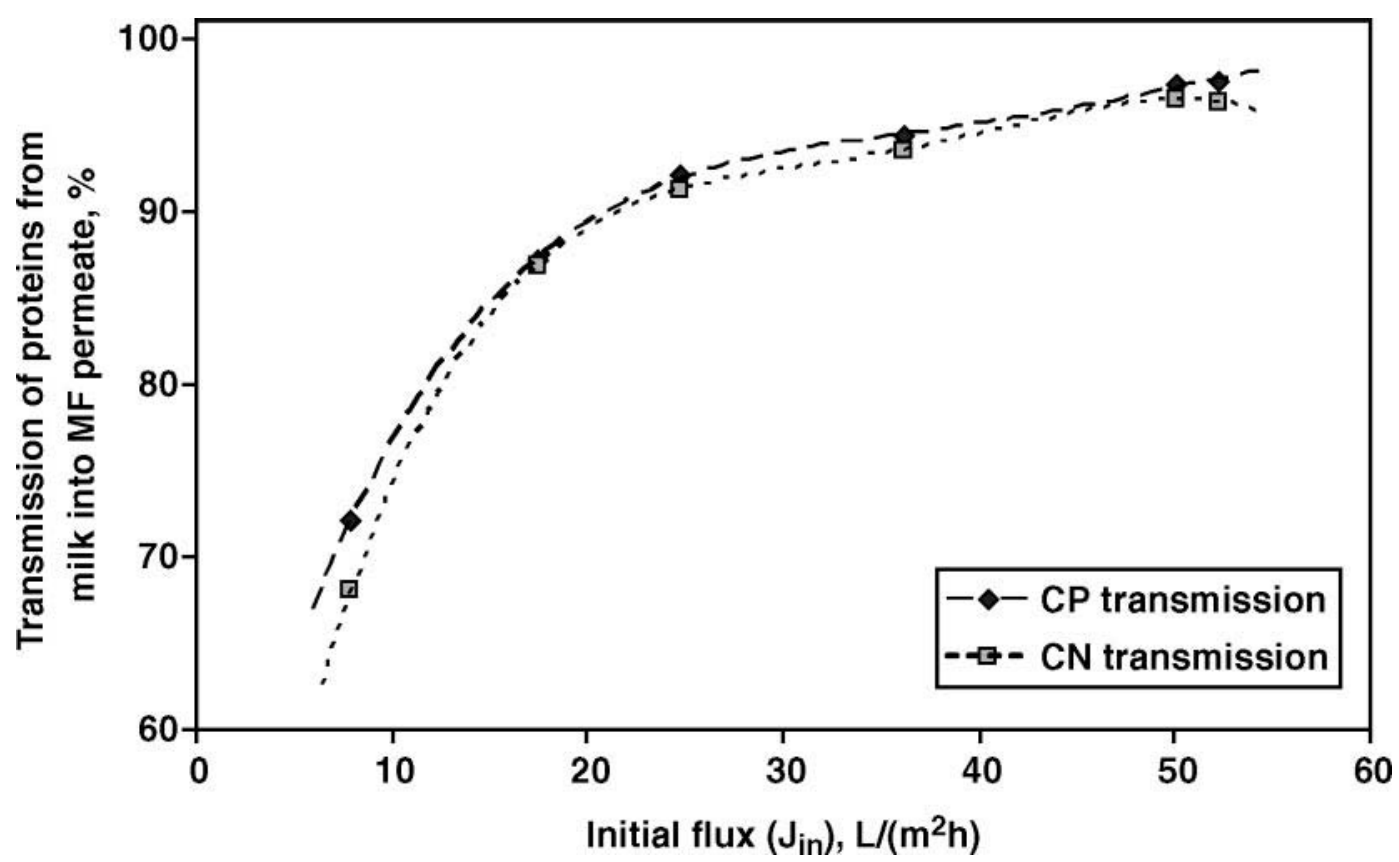

Figure 8. Correlation between separation yield (flux) and transmission of proteins into the permeate in the cold microfiltration (MF) of skim milk at $t=6 \pm 1^{\circ} \mathrm{C}$. All data points represent single MF experiments.

effect of velocity on preventing the formation of a dense fouling layer.

The fouling layer significantly altered the membrane pore size and ultimately became the "dynamic membrane" that controlled the MF process. The effect of the fouling layer on the flow through the membrane was quantified by using the cake filtration model, which is an adequate descriptor of milk MF (Guerra et al., 1997). The hydraulic resistance of the fouling layer was estimated by using the equation

$$
\mathrm{J}=\frac{\Delta \mathrm{P}_{\mathrm{tm}}}{\eta \mathrm{R}_{\mathrm{t}}}
$$

where $J$ is the flux $(\mathrm{m} / \mathrm{s}) ; \Delta \mathrm{P}_{\mathrm{tm}}$ is the TMP $(\mathrm{Pa}) ; \eta$ is the viscosity $(\mathrm{Pa} \times \mathrm{s}) ; \mathrm{R}_{\mathrm{t}}$ is the total hydraulic resistance $\left(m^{-1}\right)$; and $R_{t}$ is $R_{m}+R_{f}$, where $R_{m}$ is the hydraulic resistance of the membrane $\left(\mathrm{m}^{-1}\right)$ and $\mathrm{R}_{\mathrm{f}}$ is the hydraulic resistance of the fouling layer $\left(\mathrm{m}^{-1}\right)$.

The hydraulic resistance of the membrane was calculated from the water flux data, and it was determined to be $3 \times 10^{11} \mathrm{~m}^{-1}$. The hydraulic resistance of the fouling layer was estimated to be on the order of $10^{12}$ to $10^{13}$ $\mathrm{m}^{-1}$, depending on the experimental conditions. This demonstrates that after the fouling layer is formed, its resistance will actually control the flow through the membrane rather than the membrane itself controlling the flow.
These observations demonstrate that unless the flow pattern in the outer channels is disrupted, there will always be a more pronounced fouling of the membrane in the outer channels, regardless of the average crossflow velocity used for the MF process. To physically disrupt this fouling layer, particularly from the outer channels of the membrane, a $\mathrm{CO}_{2}$ backpulsing method was developed. Techniques involving water backflushing or gas sparging have been used before to minimize fouling in cross-flow filtration processes, but not for food applications (Ma et al., 2001). For food applications, the introduction of a secondary fluid into the process could create contamination or adulteration issues. However, with the appropriate choice of the backpulsing fluid, this solution could provide significant benefits for the MF of milk, as well as other fluid foods. In this work, $\mathrm{CO}_{2}$ was identified as an excellent medium for backpulsing because of its GRAS (Generally Recognized As Safe) status, high acceptability in the dairy industry, and known antibacterial effects.

The developed $\mathrm{CO}_{2}$ backpulsing system entailed a pressurized $\mathrm{CO}_{2}$ gas surge at the inlet of the membrane (Figure 1). Low-pressure $\mathrm{CO}_{2}$ was injected through the membrane from the permeate side to the feed side. Several combinations of pressure and time were tested and, after process optimization, a program was selected that consisted of $\mathrm{CO}_{2}$ backpulses every minute for an average duration of $10 \mathrm{~s}$ at a pressure equal to that of the inlet pressure of the feed $(138 \mathrm{kPa})$. The use of 


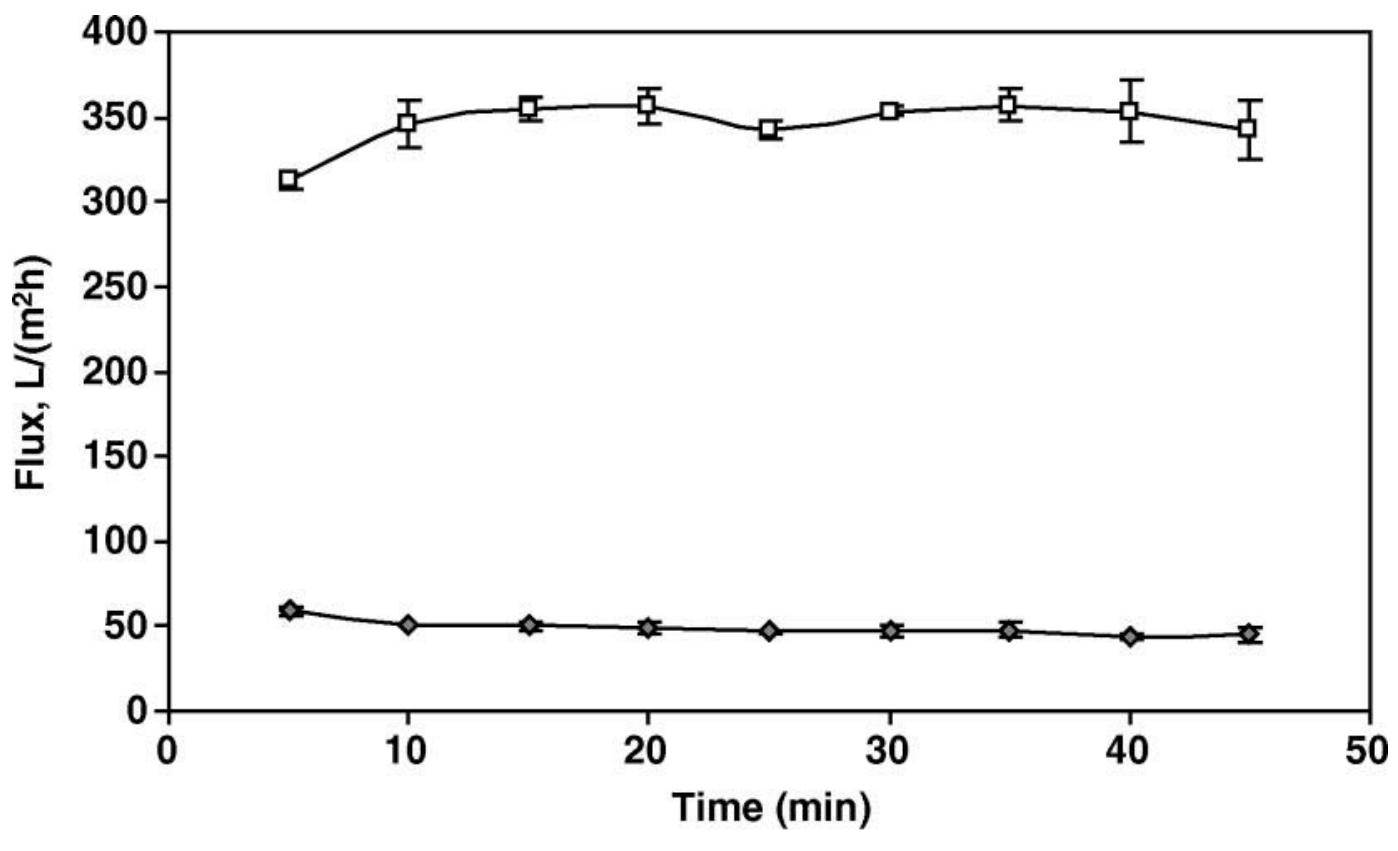

$\rightarrow-M F$ at $43 \mathrm{~F}(6 \mathrm{C}) \quad \rightarrow-\mathrm{MF}$ at $128 \mathrm{~F}(53 \mathrm{C})$

Figure 9. Permeate flux in cold $\left(6^{\circ} \mathrm{C}\right)$ microfiltration $(\mathrm{MF})$ versus warm $\left(53^{\circ} \mathrm{C}\right) \mathrm{MF}$ of raw skim milk. All experiments were performed with setup 1 under optimal processing conditions (velocity $=7 \mathrm{~m} / \mathrm{s}$, transmembrane pressure $=69 \mathrm{kPa}$ ). Error bars represent standard deviations. Water flux values: $1,167 \mathrm{~L} /\left(\mathrm{m}^{2} \mathrm{~h}\right)$ for cold $\mathrm{MF}$ and $1,015 \mathrm{~L} /\left(\mathrm{m}^{2} \mathrm{~h}\right)$ for warm $\mathrm{MF}$.

a continuous stream of $\mathrm{CO}_{2}$ was also tested, but this resulted in significant bubbling in the flow channels, which impeded the flow and had no beneficial effects on the flux.

During the $\mathrm{CO}_{2}$ backpulsing runs, the permeate flux was significantly greater and more stable than in the MF process conducted under the same TMP and crossflow velocity conditions but without gas backpulsing (Figure 11). The $\mathrm{CO}_{2}$ backpulsing led to a $20 \%$ increase in the permeate flux and a $13 \%$ increase in the total amount of permeate collected after $3 \mathrm{~h}$ of MF. Although the flux increase was still modest, one of the very prom- ising aspects of the $\mathrm{CO}_{2}$ backpulsing technique developed was its ability to maintain a more stable flux-the permeate flux decreased by only approximately $15 \%$ after $3 \mathrm{~h}$ of MF. The rate of flux decline was calculated for both the regular $\mathrm{MF}$ runs and for the $\mathrm{CO}_{2}$-aided process, and the results showed that for the latter, the rate of decline fluctuated around zero in all 3 replicate runs, whereas for the regular runs, the rate of decline was constantly greater than zero (Figure 12).

It is also important to note that the backpulsing technique has not yet been developed to its maximum potential, because in this study only one $\mathrm{CO}_{2}$ injection
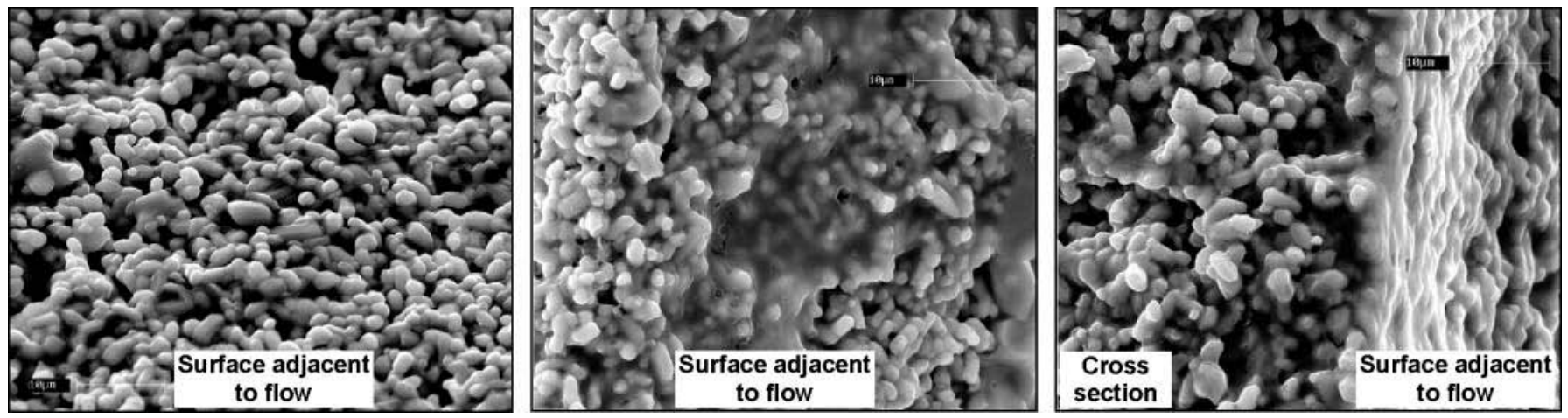

Figure 10. Scanning electron micrographs of a cleaned membrane surface (left) and of the fouling layer formed after cold skim milk microfiltration on the membrane surface of an inner channel (middle) and an outer channel (right). 
port was used. It is expected that the effectiveness of the process will be further increased by placing additional injection ports around the membrane housing as well as along the membrane. The full development of the $\mathrm{CO}_{2}$ backpulsing technique, which is the subject of an ongoing study, is expected to further increase the economical attractiveness of cold MF of skim milk.

\section{CONCLUSIONS}

In this study, we identified the optimal process parameters for low-temperature cross-flow MF with the purpose of physically removing vegetative bacteria, spores, and somatic cells from skim milk. Optimal conditions for MF of skim milk at temperatures of ap-

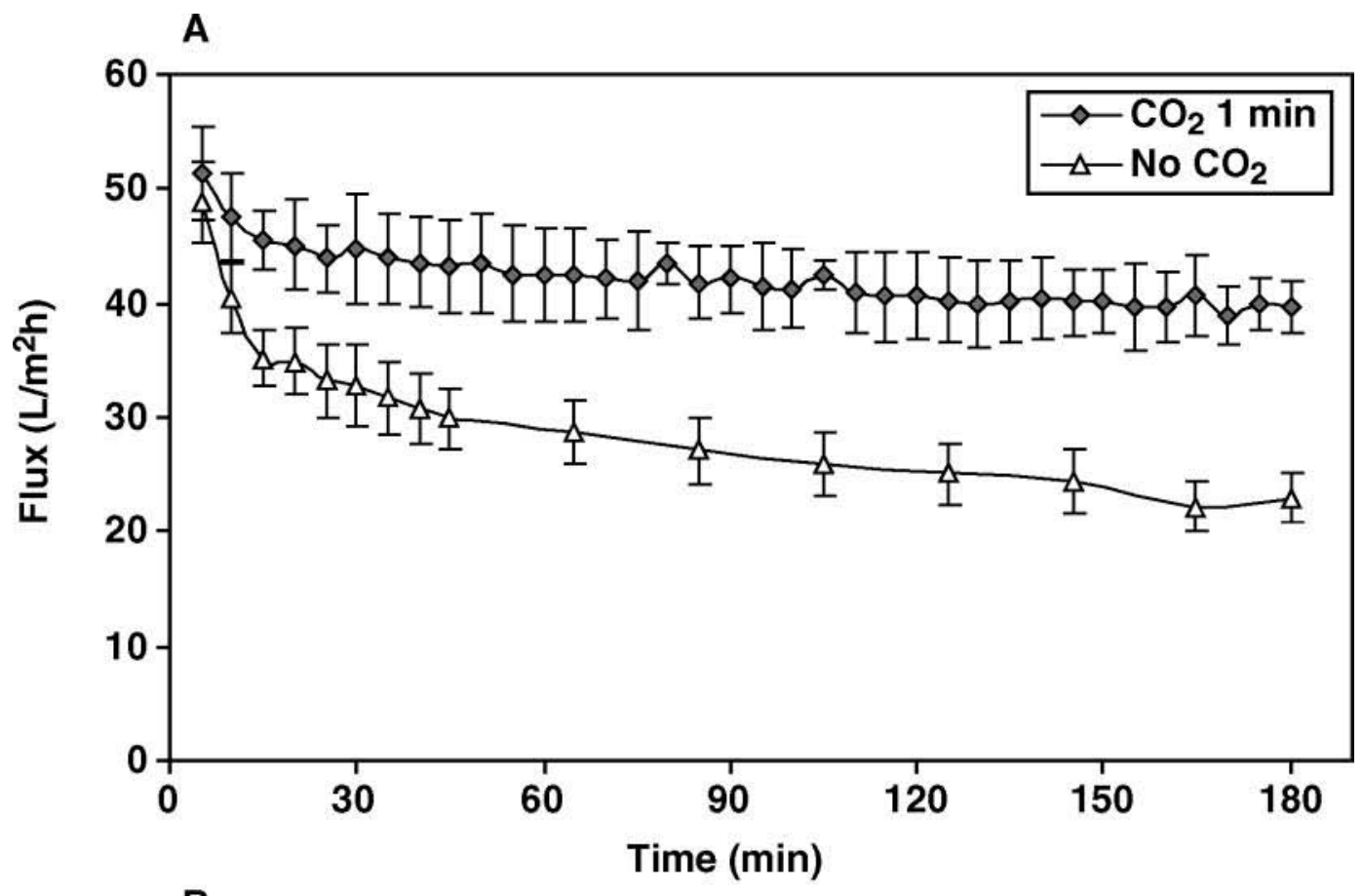

B

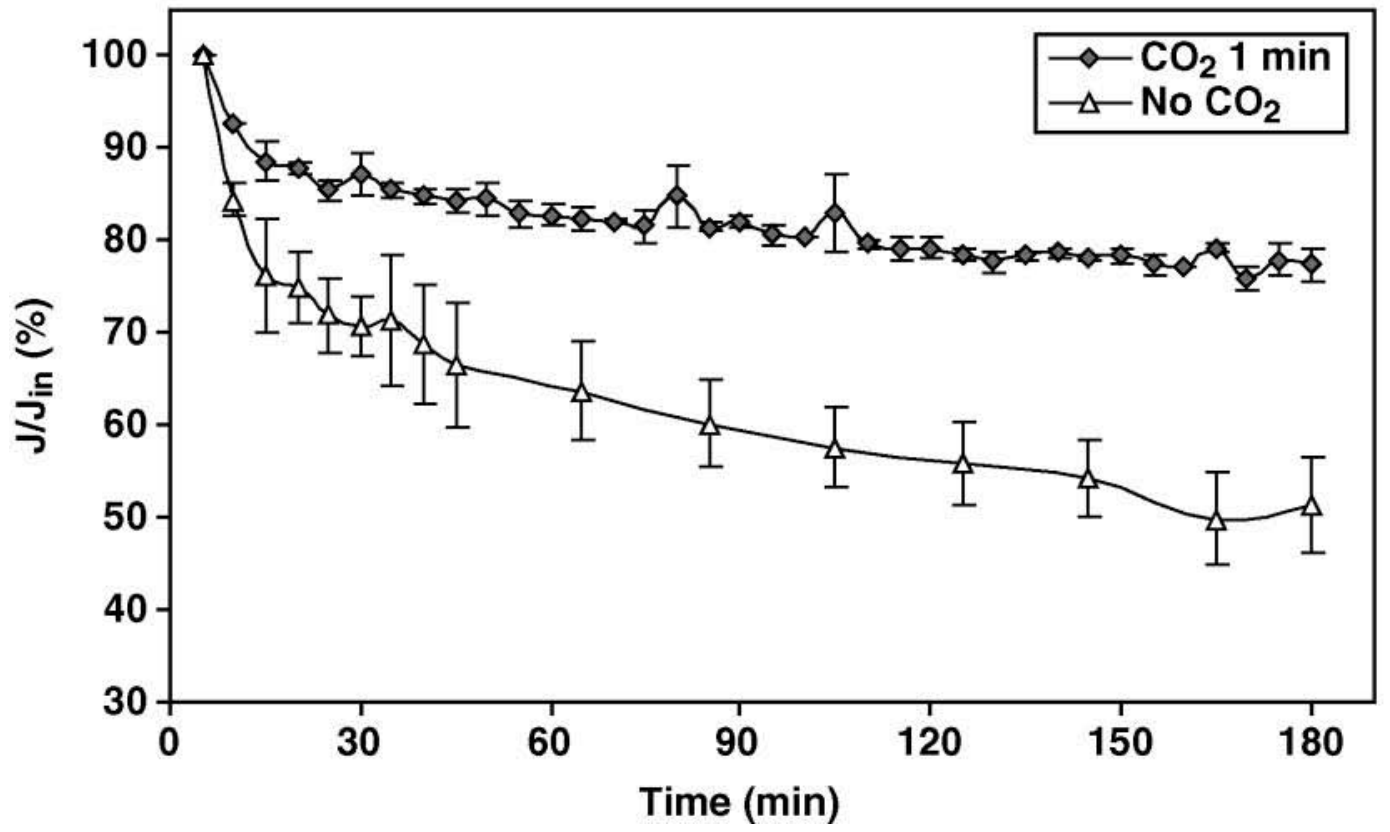

Figure 11. Permeate flux (a) and relative flux (b) in cold microfiltration (MF) of raw skim milk, with and without $\mathrm{CO}_{2}$ backpulsing. Experiments were performed with setup 2. Error bars represent standard deviations. Processing conditions: velocity $=7 \mathrm{~m} / \mathrm{s}$; transmembrane pressure $(\mathrm{TMP})=75 \mathrm{kPa}$ (in the critical TMP range); $t=6 \pm 1^{\circ} \mathrm{C}$; water flux $=889$ to $945 \mathrm{~L} /\left(\mathrm{m}^{2} \mathrm{~h}\right)$. 


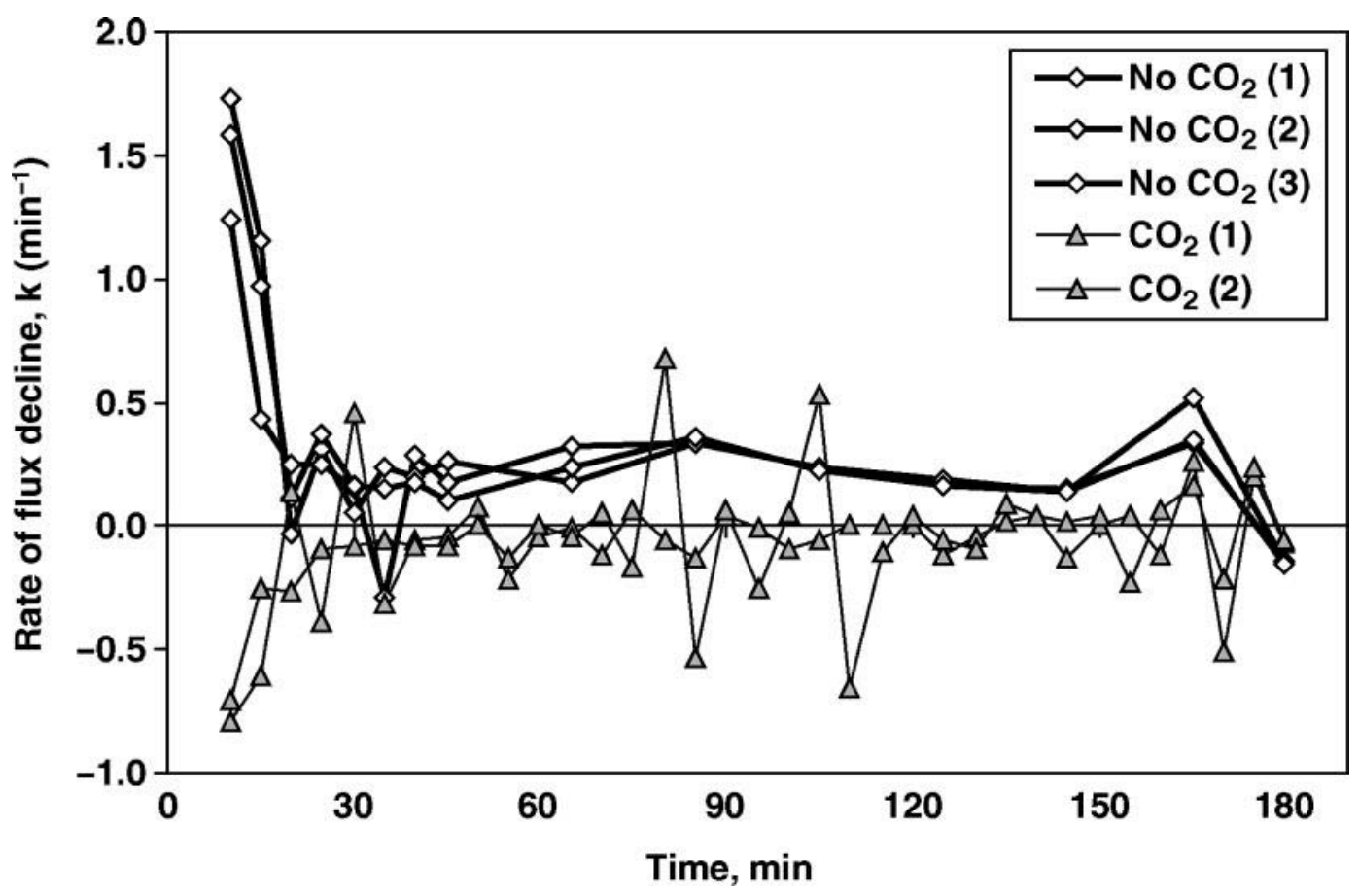

Figure 12. Rate of flux decline for experiments performed with and without $\mathrm{CO}_{2}$ backpulsing. Experiments were performed with setup 2. Processing conditions: velocity $=7 \mathrm{~m} / \mathrm{s}$; transmembrane pressure $(\mathrm{TMP})=75 \mathrm{kPa}$ (in the critical TMP range); $t=6 \pm 1^{\circ} \mathrm{C}$; water flux $=889$ to $945 \mathrm{~L} /\left(\mathrm{m}^{2} \mathrm{~h}\right)$.

proximately $43^{\circ} \mathrm{F}\left(6^{\circ} \mathrm{C}\right)$ included a cross-flow velocity of $7 \mathrm{~m} / \mathrm{s}$ and a TMP range of 60 to $85 \mathrm{kPa}$. Under these conditions, a very effective removal of vegetative bacteria cells, spores, and somatic cells from skim milk was achieved, while maintaining a protein composition in the microfiltered milk very close to that of the initial skim milk. By coupling the optimal process parameters with a $\mathrm{CO}_{2}$ backpulsing technique that disrupted the fouling layer in the outer membrane channels, greater and steadier permeate fluxes were obtained. Overall, this process has the potential to become economically attractive and to gain acceptance in the dairy industry for removal of microbes from milk, either at the farm level or in processing plants, with direct benefits for the quality and shelf life of dairy products.

\section{ACKNOWLEDGMENTS}

The authors would like to thank the New York State Milk Promotion Board (Albany, NY) for financial support, Maureen Chapman and Bob Kaltaler from David Barbano's group for help with protein analyses and pilot plant assistance, Tom Burke for technical assistance, and the Cornell Dairy staff for pilot plant support.

\section{REFERENCES}

AOAC. 2003. Official method 991.20: Nitrogen (total) in milk. Official Methods of Analysis of AOAC International. 17th ed. AOAC International, Washington, DC.
Azevedo, N. F., A. R. Pinto, N. M. Reis, M. J. Vieira, and C. W. Keevil. 2006. Shear stress, temperature, and inoculation concentration influence the adhesion of water-stressed Helicobacter pylori to stainless steel 304 and polypropylene. Appl. Environ. Microbiol. 72:2936-2941.

Azzara, C. D., and P. S. Dimick. 1985. Lipoprotein lipase activity of milk from cows with prolonged subclinical mastitis. J. Dairy Sci. 68:3171-3175.

Brans, G., C. G. P. H. Schroën, R. G. M. van der Sman, and R. M. Boom. 2004. Membrane fractionation of milk: State of the art and challenges. J. Membr. Sci. 243:263-272.

Cousin, M. A. 1982. Presence and activity of psychrotrophic bacteria microorganisms in milk and dairy products: A review. J. Food Prot. 45:172-207.

Elwell, M. W., and D. M. Barbano. 2006. Use of microfiltration to improve fluid milk quality. J. Dairy Sci. 89 (E Suppl.):E10E30.

Field, R. W., D. Wu, J. A. Howell, and B. B. Gupta. 1995. Critical flux concept for microfiltration fouling. J. Membr. Sci. 100:259-272.

Gilbert, P., D. G. Allison, and A. J. McBain. 2002. Biofilms in vitro and in vivo: Do singular mechanisms imply cross-resistance? J. Appl. Microbiol. 92:98S-110S.

Guerra, A., G. Jonsson, A. Ramussen, E. N. Waagner, and D. Edelsten. 1997. Low cross-flow velocity microfiltration of skim milk for removal of bacterial spores. Int. Dairy J. 7:849-861.

Howell, J. A. 1995. Sub-critical flux operation of microfiltration. J. Membr. Sci. 107:165-171.

Hyde, M. F. 2002. Physiology of thermophilic bacilli from dairy processing facilities, with particular reference to temperature. $\mathrm{PhD}$ Thesis. University of New South Wales, Sydney, Australia.

Kochkodan, V. M., N. Hilal, V. V. Goncharuk, L. Al-Khatib, and T. I. Levadna. 2006. Effect of the surface modification of polymer membranes on their microbiological fouling. Colloid J. 68:267273.

Law, B. A. 1979. Reviews of the progress of dairy science: Enzymes of psychrotrophic bacteria and their effects on milk and milk products. J. Dairy Res. 46:573-593. 
Lynch, J. M., D. M. Barbano, and J. R. Fleming. 1998. Indirect and direct determination of the casein content of milk by Kjeldahl nitrogen analysis: Collaborative study. J. AOAC 81:763-774.

Ma, H., L. F. Hakim, C. N. Bowman, and R. H. Davis. 2001. Factors affecting membrane fouling reduction by surface modification and backpulsing. J. Membr. Sci. 189:255-270.

Murphy, P.M., D. Lynch, and P. M. Kelly. 1999. Growth of thermophilic spore forming bacilli in milk during the manufacture of low heat powders. Int. J. Dairy Technol. 52:45-50.

Pafylias, I., M. Cheryan, M. A. Mehaia, and N. Saglam. 1996. Microfiltration of milk with ceramic membranes. Food Res. Int 29:141-146.
Parkar, S. G., S. H. Flint, J. S. Palmer, and J. D. Brooks. 2001. Factors influencing attachment of thermophilic bacilli to stainless steel J. Appl. Microbiol. 90:901-908.

Saboya, L. V., and J.-L. Maubois. 2000. Current developments of microfiltration technology in the dairy industry. Lait 80:541553.

Scott, S. A., J. D. Brooks, J. Rakonjac, and K. M. R. Walter. 2007. The formation of thermophilic spores during the manufacture of whole milk powder. Int. J. Dairy Technol. 60:109-117.

Verdi, R. J., and D. M. Barbano. 1988. Preliminary investigation of the properties of somatic cell proteases. J. Dairy Sci. 71:534538 . 